\title{
Long-term Performance of Going Public through SPACs*
}

\author{
Youngkyu Park** , Professor, Catholic University of Korea
}

\begin{abstract}
$\langle$ Abstract $\rangle$
Despite a surge in the merger of companies listed on the KOSDAQ market with special purpose acquisition companies (SPACs), limited domestic studies have systematically compared the listing through SPAC mergers and the general IPO. This study analyzes the impact of such companies going public after merging with SPACs as well as their performance by comparing them with the conventional IPOs. First, the firms listed through SPAC mergers are smaller and have a higher proportion of non-manufacturing industries than the conventional IPOs. Second, the operational and stock price performance of the firms listed through SPACs are not inferior to that of the conventional IPOs. Finally, a higher share allocation to institutional investors and subscription rates, for the shares recorded at the time of the SPAC listing, are related to the stock price performance observed after SPAC mergers. According to the empirical results of this study, going public by merging with SPACs provides early listing opportunities to small- and medium-sized companies; they do not experience a deterioration in their financial performance after being listed. The listing of SPACs creates a different and valuable path to enter the KOSDAQ market for such companies as compared to the conventional IPOs.
\end{abstract}

Keywords: SPACs; Merger; IPO; Back-Door Listings; Financial Performance

JEL Classification: G30, G34

* This study was supported by the Research Fund, 2020 of The Catholic University of Korea.

** Corresponding Author. Address: Catholic University of Korea, 43 Jibong-ro, Bucheon-si, Gyeonggi-do, Korea 14662; E-mail: ykpark@catholic.ac.kr; Tel: +82-2-2164-4786, Fax: +82-2-2164-4782.

Received: May 31, 2021; Revised: September 29, 2021; Accepted: October 12, 2021 


\title{
스팩합병 코스닥상장 기업의 재무성과*
}

박 영 규 (가톨릭대학교 교수)**

\author{
〈요 약〉
}

스팩과 합병하여 코스닥시장에 상장하는 기업(스팩합병 상장기업)의 급증에도 불구하고 스팩합병 상장과 일반상장(IPO)을 체계적으로 분석한 국내연구는 부족하다. 본 연구는 스팩합병 상장기업과 일반상장기업의 특성과 재무성과를 비교·분석하여 스팩의 유용성과 가치를 발견한다. 첫 번째, 스팩합병 상장기업은 일반상장기업보다 규모가 작고 제조업 외 업종비중이 높다. 두 번째, 스팩합병 상장기업의 영업성과와 주가성과가 일반상장기업보다 열등하지 않고 유사하다. 세 번째, 스팩공모 당시 기관투자자 배정비율과 청약률이 스팩합병 상장이후 성과와 연관된다. 본 연구의 실증결과를 정리하면 스팩합병 상장은 우량 중소기업에 조기상장기회를 제공하고 있음에도 일반상장기업과 비교하면 재무성과가 열등하지 않다. 즉, 스팩합병 상장은 가치 있는 코스닥시장 진입 경로이며 기존 일반상장과 차별화된 유용성이 존재한다.

핵심 단어 : 스팩, 합병, 상장, IPO, 재무성과

JEL 분류기호: G30, G34

* 본 연구는 2020년도 가톨릭대학교 교비연구비의 지원으로 이루어졌음.

** 연락담당 저자. 주소: 경기도 부천시 지봉로 43 가톨릭대학교 경영학과, 14662 ;

E-mail: ykpark@catholic.ac.kr; Tel: 02-2164-4786; Fax: 02-2164-4782. 


\section{1. 서론}

비상장기업은 $\mathrm{IPO}$ 를 거쳐 상장기업의 지위를 취득하는 전통적인 방법 외에 다른 대안을 선택할 수 있다. 대표적인 방법이 우회상장과 스팩합병 상장이다. 우회상장은 비상장기업이 상장기업의 경영권을 인수함으로써 상장기업의 지위를 취득하는 방법이며, 일부 비상장기업이 시간과 비용을 절감하여 상장 지위를 취득하는 수단으로 이용한다. 거래소의 상장된 스팩과 합병과정을 통해 상장 지위를 취득하는 스팩합병 상장 또한 우회상장과 유사한 특성이 있다.1)

비상장기업의 상장 지위 달성이라는 면에서 우회상장과 스팩합병 상장은 같다.2) 우회상장은 비상장기업이 합병의 주체이지만 스팩합병은 거래소에 상장된 스팩이 합병의 주체라는 점에서 차이가 있다. 스팩의 차별화된 특성은 합병기업선정과 향후 성과에 영향을 미칠 것이 명백하다.

우회상장은 기업실사(due diligence) 등을 적용받지 않을 뿐 아니라 2010년 이전에는 실질 심사가 면제되어 일반상장보다 완화된 요건이 적용된다. 하지만 상장이후 조기 부실화 및 상장폐지 등의 부정적인 효과가 심각하여 제도개선이 이루어진다. 2011년 우회상장 비상장기업에도 실질심사가 적용되면서 우회상장은 대폭 감소한다.

스팩은 다른 기업과의 합병이 유일한 목적인 명목회사이다. 2009년 12월 도입되어 비상장기업에 신속한 상장기회를 제공하고 있다. 비상장기업은 스팩과 합병을 거쳐 장내시장에 진입할 수 있다. 우회상장의 심사가 강화되고 스팩이 도입되면서, 스팩합병 상장이 기존 우회상장을 자연스럽게 대체하게 된다. 스팩합병 상장은 우회상장과 비교하면 명확한 장점이 존재하다. 우선 스팩은 주식시장으로부터 공모자금을 조달하여 상장 및 합병이 이루어지며, 조달자금은 합병기업의 자산으로 편입된다. 우회상장과 비교하면 합병 외에 자금조달 효과를 얻을 수 있다. 스팩 경영진의 보상은 합병 후 성과와 연결되어 있어, 이들에게 우량 비상장기업을 탐색 및 합병시킬 동기가 부여된다. 따라서 스팩합병 상장은 우회상장보다 합병이후 부실화 가능성을 감소시킬 수 있겠다. 부실한 비상장기업이 부실한 상장기업과 합병할 가능성이 큰 우회상장과는 확연한 차이다. 하지만 스팩에서 기대되는 긍정적 효과에도 불구하고, 해외선행연구는 IPO 대비 스팩합병 상장의 재무성과에 대한 부정적 실증결과를 보고한다(Datar et al., 2012; Dimitrova, 2017; Kolb and Tykvova, 2016).

스팩합병 상장의 우회상장 대비 우수성은 쉽게 이해되지만, 해외선행연구의 결과를 고려하면 과연 일반상장(IPO)보다 국내주식시장의 우수한 상장수단일까?3) 최근 국내주식시장 스팩합병 상장기업의 증가와 함께 관련 연구가 확대되고 있다. 스팩 상장일, 합병일 등 주요 공시일에 대한 주가성과부터 스팩합병 상장과 IPO 상장의 결정요인 분석, 상장이후 주가성과 등으로

1) 본 논문에서는 스팩과 비상장기업의 합병을 줄여서 스팩합병으로, 스팩합병에 의한 비상장기업의 상장을 스팩합병 상장으로 지칭한다.

2) 스팩합병 상장도 우회상장의 범주로 간주할 수도 있지만, 스팩 경영진이 주도하는 스팩합병 상장과 비상장기업 경영진이 의사결정 하는 우회상장의 차이를 구분하기 위해서, 본 연구는 우회상장과 스팩합병 상장을 각각 구별하여 사용한다.

3) 비상장기업이 IPO를 거쳐 거래소에 상장되는 과정을 IPO로 지칭한다. 본 연구는 IPO 용어와 더불어 상장을 강조하기 위해서 일반상장 용어를 함께 사용한다. 
다양해지고 있다. 합병상장 이후 장기주가성과 연구로는 Kim and Kang(2019)과 Kim and Lee(2019)가 있지만 장기영업 성과를 분석한 연구는 확인되지 않는다.

스팩합병 상장이 일반상장과는 차별화된 경로를 제공할 때 더욱 유용하고 가치 있다. 하지만, 상장이후 재무성과가 일반상장 기업보다 상당히 열악하다면 스팩합병 상장의 가치는 낮으며, 부정적 효과를 막기 위한 규제강화가 필요하겠다. 스팩합병 상장기업의 유용성 평가는 국내 스팩합병 상장기업과 일반상장기업의 특성 차이뿐만 아니라 장기재무성과를 비교해야 한다. 스팩합병 상장과 일반상장의 결정요인에 대한 조사는 이루어졌지만(Cha et al., 2019; Hong and Yang, 2021) 스팩합병 상장이후 재무성과 분석은 미흡하다. 물론 스팩합병 상장과 일반상장의 상장이후 주가성과를 분석한 연구는 존재하지만(Kim and Lee, 2019; Kim and Kang, 2019) 이들 연구 또한 IPO 기업과의 주가성과 차이를 검증하지 않는다.

본 연구는 스팩합병 상장기업과 일반상장기업의 특성 차이뿐만 아니라 상장이후 주가성과와 영업성과로 분석을 확대하여, 스팩합병 상장의 유용성을 규명한다. 스팩합병 상장기업 대부분이 코스닥시장으로 진입하고 있어 코스닥시장으로 분석대상을 한정한다. 실증분석을 통해 다음의 결과를 발견한다. 먼저, 스팩합병 상장은 일반상장과는 차별화된 상장기회를 제공한다. 스팩합병 상장기업은 일반상장기업보다 기업규모가 작고 제조업종 외 비중이 높게 나타나고 있어, 당장 코스닥시장 일반상장이 곤란한 기업에 상장기회를 제공한다. 다음으로 스팩합병 상장기업의 주가성과와 영업성과 모두 일반상장기업보다 열등하지 않다. 선량한 개인투자자에게 심각한 피해를 준 우회상장의 부정적 효과가 발견되지 않고 있어, 우량 중소기업의 신속한 코스닥시장 진입을 지원하는 유용성이 확인된다.

본 연구는 다음과 같이 구성된다. 제 2 장은 스팩과 선행연구 내용을 정리하고, 제 3 장은 연구목적, 연구방법 및 연구모형과 표본을 자세하게 기술하고, 제 4장은 연구모형을 분석한 실증결과를 설명한다. 마지막으로 제 5 장에서 결론을 기술한다.

\section{2. 스팩과 선행연구}

\section{1 스팩합병 상장과 일반상장}

$\mathrm{SPAC}$ (special purpose acquisition company)은 “공모(IPO)를 통해 조달한 자금을 바탕으로 다른 기업과 합병하는 것을 유일한 목적으로 하는 명목회사(paper company)입니다.”4) 2008년 글로벌 금융위기 여파로 침체된 국내 기업공개 시장을 지원하기 위해서 정부가 2009년 도입 하였으며, 비상장기업에게 신속한 상장기회를 제공한다.

스팩은 주식회사와 동일한 절차로 설립되며, 공모과정을 거쳐 거래소에 상장된다. 국내 스팩 대부분은 코스닥시장에 상장되어 비상장기업의 코스닥시장 상장을 돕는다.5) 공모자금의 $90 \%$

4) 한국거래소 홈페이지의 “상장개요" 하부항목인 SPAC의 개요설명에 기술되어 있다 (https://listing.krx.co.kr/contents/LST/02/02070100/LST02070100.jsp).

5) 한국거래소 공시사이트의 자료에 의하면, 2010년 3개의 스팩이 유가증권시장에 상장된 이후 2020년까지 유가증권시장에 상장된 스팩은 존재하지 않는다. 
한국증권학회지 제 51 권 1호 (2022)

이상이 별도 예치되며 인출 및 담보제공이 금지된다는 점에서 투자자에게 높은 투자 안정성을 제공한다. 스팩의 최장 존속기간은 3 년이며, 이 기간에 스팩 경영진은 합병대상 비상장법인 탐색을 지속한다. 합병대상 기업의 가치는 의무예치금액의 $80 \%$ 이상이 되어야 하며, 스팩법인 발기인과 이해관계 회사는 대상이 될 수 없다.

경영진이 합병대상 기업을 탐색하고 결정하게 되면 이사회결의를 거쳐 합병을 공시한다. 합병상장에 필요한 관련 서류와 합병상장 예비심사청구서를 제출하면 비상장기업에 대한 상장적격성 심사를 받게 된다. 거래소로부터 합병상장심사 승인을 통보받은 이후, 최종적으로 합병결의를 위한 주주총회가 개최되는데 발기인의 의결권 행사는 제한되어 일반주주의 의사에 의해 합병이 결정된다. 주주총회에서 합병안건이 통과되면 스팩은 비상장법인과 합병되고 합병회사는 거래소에 존속된다. 만약, 존속기간 내 합병법인탐색에 실패하거나 주주총회에서 합병 찬성이 실패하는 경우 예치금은 반환되고 스팩은 해산된다.

스팩투자자의 이익 실현은 합병이 실현되는 경우와 합병실패로 스팩이 해산되는 때에 따라 다르다. 합병이 성공한 스팩의 주주는 합병이후까지 주식을 보유해 이익을 실현할 수 있다. 또한, 합병을 반대하는 투자자는 주식매수청구권을 행사하여 투자이익을 회수할 수 있다. 상장 기간 합병에 실패하면 투자자는 일정 기간 이후 예치금을 수령한다.

비상장기업이 스팩과의 합병을 통해 상장기업이 된다는 점에서 스팩합병 상장은 외관상 우회상장과 일치한다. 하지만 스팩합병 상장은 우회상장과 비교하면 우량한 특성이 존재한다. 먼저, 스팩은 공모과정을 거쳐 거래소에 상장되며 조달된 자금은 의무적으로 금융기관에 예치되며, 합병이후 스팩상장으로 조달된 자금은 합병기업의 자산으로 전환된다. 신규자금조달 효과가 배제되는 우회상장에 비해 스팩합병 상장은 $\mathrm{IPO}$ 와 유사하게 자금조달 효과를 얻게 되어, 합병이후 부실화 가능성이 현저히 감소한다. 우회상장의 경우 비상장기업이 합병대상을 탐색하는 주체이기 때문에, 조속한 상장을 추진하는 과정에서 부실 상장기업과 합병하여 조기 부실화로 진행될 유인이 높다. 반면에 스팩경영진의 보상이 합병이후 성과와 연계되어 있어, 합병추진 주체인 스팩경영진은 우량한 비상장기업과의 합병을 시도할 유인이 높다.

스팩의 장점에도 불구하고 미국 주식시장 선행연구들은 스팩합병 상장기업의 불량한 성과를 보여주고 있어(Datar et al., 2012; Dimitrova, 2017; Kolb and Tykvova, 2016), 국내 스팩합병 상장에 대한 검증이 필요하다.

일반상장을 준비하는 기업은 코스닥시장 상장요건을 충족시켜야 하며 거래소의 재무내용, 주식분산 등 외형요건과 기업계속성, 경영투명성 등 질적요건에 대한 심사를 거쳐 상장지위를 획득할 수 있다. 비상장기업은 상장에 필요한 사항을 점검하고 준비한 이후, 상장예비심사 청구서류를 거래소에 제출함으로써 상장신청을 한다. 상장예비심사를 통과하면 증권신고서 제출, 수요예측, 공모가확정 등 공모절차를 진행한다. 공모절차가 종료되면 법인은 상장신청서를 제출하고 코스닥시장 매매거래가 개시됨으로써 상장절차가 완료된다.

스팩합병 상장과 일반상장의 내용은 <표 $1>$ 로 요약된다.6) 스팩과 합병하는 비상장법인에

6) Kang and $\operatorname{Kim}(2018)$ 의 <표 1>을 참고하여 스팩합병 상장과 일반상장의 내용을 작성한 표이다. 
대한 심사요건은 외형심사와 질적심사로 구성되며 일반상장과 매우 유사하다. SPAC 공모예치 자금의 $80 \%$ 이상의 피합병 법인 규모를 요구하는 외형요건은 큰 차이점이다.

〈표 1〉 스팩합병 상장과 일반상장의 비교

Kang and $\operatorname{Kim}(2018)$ 의 <표 1>의 내용을 참고하여 코스닥시장의 스팩합병 상장과 일반상장을 비교한다.

\begin{tabular}{|c|c|c|}
\hline & 스팩합병 상장 & 일반상장 \\
\hline 심사요건 & $\begin{array}{l}\text { - 외형심사 } \\
\text { 이익규모, 감사의견, 주식양도제한, 합병대 } \\
\text { 상법인규모 } \\
\text { - 질적심사 } \\
\text { 기업경영의 계속성, 지배구조 및 경영의 투명 } \\
\text { 성 등을 중심으로 신규상장 심사기준을 준용 }\end{array}$ & $\begin{array}{l}\text { - 외형심사 } \\
\text { 주식분산, 경영성과 및 시장평가 등, 감사 } \\
\text { 의견, 지배구조, 주식양도제한 } \\
\text { - 질적심사 } \\
\text { 기업 계속성, 경영 투명성 - 안정성, } \\
\text { 투자자보호 }\end{array}$ \\
\hline 자금조달 & $\begin{array}{l}\text { - SPAC 공모자금, 회사채 발행자금 } \\
\text { - 공모시장 여건의 영향이 적음 }\end{array}$ & $\begin{array}{l}\text { - 신규공모 } \\
\text { • 공모시장 여건의 영향 }\end{array}$ \\
\hline 주요특징 & $\begin{array}{l}\text { - } \mathrm{SPAC} \text { 발기인의 지분보유로 우량기업 발굴 } \\
\text { 유인 } \\
\text { - 우회상장기업 부실화에 대한 대응으로 도입 }\end{array}$ & $\begin{array}{l}\text { - 공모가 저평가 가능성 } \\
\text { - 상장주선인 의무인수 규정 }\end{array}$ \\
\hline
\end{tabular}

일반상장과 스팩합병 상장 모두 $\mathrm{IPO}$ 를 통한 자금조달을 거치지만, 스팩합병 상장은 스팩상장 시점에 자금이 조달되기 때문에 합병 시점의 공모시장 여건에서 일반상장보다 자유롭다. 스팩 발기인은 주식과 전환사채로 스팩의 지분을 소유하고 있어 합병 후 성과에 보상이 연동되며, 우량기업을 탐색 및 발굴할 유인이 있어 비상장기업을 고평가할 유인 또한 낮다(Kang and Kim, 2018).

\section{2 선행연구}

해외 스팩연구는 스팩 특성과 합병 성공에 관한 연구와 스팩 성과분석에 관한 연구로 분류된다. 먼저, 스팩 특성의 합병에 대한 영향을 분석한 연구로는 Lakicevic and Vulanovic(2011), Lakicevic et al.(2014), Cumming et al.(2014)이 발견된다.

Lakicevic and Vulanovic(2011)은 스팩특성의 합병에 대한 영향을 조사하여 다음의 실증 결과를 발견한다. 먼저 스팩규모는 비상장기업과의 합병에 부정적이다. 스팩 IPO에 특화된 Early Bird Capital의 인수기관 참여는 상장이후 합병성과를 높인다. Cumming et al.(2014)은 미국주식시장의 SPAC 합병승인에 대한 영향요인을 규명한다. 2003월 9월부터 2011년 1월까지 스팩을 분석하여 경영진 경험, 인수자 규모와 명성이 합병성공과 연관성이 높지 않다는 결과를 보고한다. 또한, 사모펀드와 헤지펀드 투자자의 참여는 오히려 합병 성공에 부정적이다. Lakicevic et al.(2014)은 2003년부터 2012년까지 미국주식시장에 상장된 184개 스팩의 특성과 합병 성공을 분석한다. 스팩 설립자의 특성과 관련해서는 스팩에 참여한 설립자의 수(+)가 많을수록, 스팩 참여 유경험 설립자일수록 합병 성공에 긍정적이다. 특정 국가나 업종을 목표로 하는 스팩일수록 합병 성공률이 높다. 특히 중국의 비상장기업과의 합병 성공 가능성이 크다. 
한국증권학회지 제51권 1호 (2022)

스팩 성과는 합병공시일 등에 대한 주가수익률과 합병이후 재무성과로 측정된다. 스팩 합병 공시일에 대한 시장반응은 긍정적이지만 합병완료일에는 부정적으로 전환되는 현상이 관측된다. Ignatyeva et al.(2013)은 2005년 이후 유럽주식시장에 상장된 19개 스팩을 조사하여 합병 공시 후 2.5\%의 수익률을 발견한다. Lakicevic and Vulanovic(2013)은 2003년부터 2009년 까지의 미국시장에 상장된 $\mathrm{SPAC}$ 의 $\mathrm{IPO}$ 와 합병을 분석한 결과, 스팩 합병공시일에 양(+)의 초과수익률을 발견한다. 이는 현금인수합병기업의 양 $(+)$ 의 초과수익률과 일치하는 현상이라고 설명한다. 합병일에 대한 시장반응은 스팩증권의 종류마다 차이가 있으며, 보통주의 경우 합병일에 대한 부정적 시장반응이 관측된다. Floros and Sapp(2011)은 SPAC과 역합병(reverse merger)과의 비교연구에서 SPAC의 IPO, 합병공시일, 합병종료일에 대한 초과수익률을 측정한다. 스팩상장에 대한 초과수익률은 0 이며, 합병대상 공시에는 양 $(+)$ 의 초과수익률이지만 합병완료 공시이후에는 음(-)으로 초과수익률이 반전된다. Jenkinson and Sousa(2011)는 2003년부터 2008년까지 미국주식시장에 상장된 스팩을 분석한 결과, 주주총회에서 합병이 결정된 이후 음(-)의 수익률을 발견한다. 저자들은 $\mathrm{SPAC}$ 의 장점에도 불구하고 합병거래 승인의 절반 이상에서 즉시 가치가 파괴되고 있어 투자자의 주의 환기가 필요하다고 주장한다.

스팩합병 상장의 장기성과를 측정한 연구는 $\mathrm{IPO}$ 기업과 스팩합병 기업의 특성을 함께 분석한다 (Datar et al., 2012; Dimitrova, 2017; Kolb and Tykvova, 2016). Datar et al.(2012)은 미국주식시장 스팩합병 상장기업과 전통적인 IPO 기업의 재무성과를 비교·분석한다. 스팩합병 기업의 영업성과는 동종 업종 및 IPO 기업보다 낮다. 스팩합병 대상기업의 부채의존도가 높고 소기업일수록 IPO 기업보다 투자 수준과 성장기회가 낮다. Kolb and Tykvova(2016)는 미국시장의 스팩합병 127 건과 1128 개 $\mathrm{IPO}$ 를 조사하여, 성장기회가 낮고 규모가 작고 부채비율이 높은 기업일수록 $\mathrm{IPO}$ 보다 스팩합병 상장을 선택하는 결과를 보고한다. 주식시장의 변동성과 부채비용 또한 스팩과 IPO 선택에 영향을 준다. 시장, 업종, 규모와 장부가/시장가(BM)를 벤치마크로 측정된 스팩합병 기업의 보유초과수익률(BHAR)은 장기저성과가 나타나며, IPO 기업보다 심각하다. Dimitrova(2017)는 Datar et al.(2012)의 연구와 유사하게 스팩합병의 주가성과와 회계성과를 분석한다. 주가성과의 벤치마크는 주가지수(Russell2000)와 산업과 기업규모, $\mathrm{IPO}$ 기업이다. 합병이후 장기주가성과(BHR)는 벤치마크보다 열등하며, 특히 IPO 기업에 비해서도 낮다. 영업성과는 업종, 업종과 규모, IPO 기업 등을 차감하여 측정되며, 벤치마크 종류와 상관없이 합병이후 성과는 음(-)의 값으로 열등하다. 해외 선행연구는 스팩합병 상장의 $\mathrm{IPO}$ 보다 심각한 장기 저성과현상을 보고한다.

국내주식시장의 스팩도입 이전연구는 스팩관련 법률적 및 제도적인 주제이며 $(\mathrm{Kim}, 2008$; $\mathrm{Kim}, 2010 \mathrm{a}, 2010 \mathrm{~b} ; \mathrm{Oh}, 2010)$, 실제 2009년 스팩도입 이후 실증연구가 시작된다. 초기 연구는 스팩 상장일, 합병일 등 주요 공시일에 대한 주가성과 분석이며, 스팩 상장의 증가와 함께 일반상장과의 특성비교 등으로 연구가 확대 및 다양해진다.

Lee(2014)는 2009년부터 2011년까지 상장된 22개 SPAC의 특성과 상장이후 주가를 분석한다. 10 개 스팩은 비상장기업과 합병에 성공하고 나머지는 해산된다. 스팩의 주가는 상장 이후 1 년 시점에 공모가격을 밑돌다가 2년 시점에 회복하는 형태를 보인다. 상장일 종가를 공모가로 
나눈 IPO 초기수익률(초기성과)의 평균값은 $4.52 \%$ 이다. 합병 공시 이전 25 일간의 누적평균 초과수익률은 $2.94 \%$ 로 유의하다. Lee(2014)는 초기 실증연구로서 의의가 있지만 표본 개수의 한계를 고려하면 해석에 주의가 필요하다. Lee(2017)는 2010년부터 2015년까지 주식시장에 상장된 SPAC으로 확대하여 성과를 분석한다. 스팩상장일, 합병공시일, 합병기일의 초과수익률을 측정하였으며, 합병공시일부터 합병기일까지 수익률이 지속해서 상승하는 반면에 합병기일 이후 50일까지 수익률은 유의하지는 않지만, 음(-)의 수치로 반전된다.

재무분야 연구가 주가성과에 초점을 두고 있다면, 회계분야는 상장 전 이익조정행위를 분석 한다. Min and Cha(2017)는 스팩합병 상장기업을 비상장 외감기업과 코스닥 일반상장 기업과 이익조정을 비교하여, 스팩합병 상장기업의 상장 직전년도 이익조정이 두 집단에 비해 과도하다는 증거를 발견한다.

Min and Cha(2017)의 연구는 IPO 기업과 스팩합병 상장기업을 비교·분석한 의의가 있지만, 이익조정분석에 한정된다. Cha et al.(2019)과 Hong and Yang(2021)은 일반상장과 스팩합병 상장기업의 차이분석으로 연구를 확장한다. Cha et al.(2019)은 기업의 규모가 작을수록, 업력이 짧을수록, 부채비율이 높을수록, 매출액영업이익률이 낮을수록, 매출액증가율이 낮을수록 $\mathrm{IPO}$ 보다 스팩 합병상장을 선호하는 실증결과를 보고한다. 최대주주지분율과 R\&D 집약도 또한 $\mathrm{IPO}$ 와 스팩 합병상장 선택에 영향을 준다. Cha et al.(2019)이 기업 및 재무특성에 집중했다면, Hong and Yang(2021)은 상장절차특성 변수까지 결정요인 분석에 포함한다. 이들은 스팩 합병상장의 IPO 상장 대비 긴 상장소요기간이 높은 상장난이도 때문이라고 주장한다. 스팩합병 상장시점의 기업가치가 $\mathrm{IPO}$ 상장보다 높으며, IPO 상장 과정의 공모가격 조정이 스팩합병 절차에 존재하지 않을 뿐만 아니라 자율적 합병가격 산정에 기인한 결과로 유추한다. 대표이사 나이가 낮을수록 $\mathrm{IPO}$ 상장보다는 스팩합병 상장을 선택한다. 스팩상장의 주간사가 IPO 상장보다 규모가 작은데, 스팩상장은 주간사의 규모보다는 스팩상장에 특화된 주간사가 선택되기 때문이다.

스팩합병 상장기업의 상장이후 장기성과를 측정한 연구는 $\mathrm{Kim}$ ad Lee(2019)와 Kim and Kang(2019)이 있다. Kim and Lee(2019)는 2000년부터 2014년까지 IPO 상장, 우회상장과 스팩상장의 장기성과를 분석한다. 저자들은 주가지수와 기업규모와 장부가/시장가 $(\mathrm{BM})$ 비율 포트폴리오를 벤치마크로 측정된 초과수익률을 분석한다. 상장유형과 무관하게 기업규모와 $\mathrm{BM}$ 포트폴리오 조정 초과수익률은 모두 음(-)이지만 시장지수조정 초과수익률에서는 장기 저성과현상이 나타나지 않는다. 스팩합병 상장이후의 저성과를 발견한 의의가 있지만 분석대상이 21 개에 불과하며, 스팩합병 상장과 IPO 상장의 장기성과를 비교분석하지 않는다. $\mathrm{Kim}$ and $\operatorname{Kang}$ (2019)은 2017년까지 합병에 성공한 56개 스팩의 합병공시일, 합병기일 등에 대한 공시 효과와 합병상장일 이후 1년간 장기성과를 조사한다. Kim and Lee(2019)보다 많은 스팩합병 상장을 분석하지만 주가성과 측정기간이 1 년에 불과하다. 합병상장일 이후 누적평균초과수익률 (CAAR)은 관측기간과 상관없이 음(-)의 값으로 나타나, 합병에 대한 긍정적인 효과는 발생하지 않는다. 합병대상 기업의 ROE가 높고 존속기간이 길수록, 합병비율이 낮을수록 합병상장일 이후 초과수익률은 높아진다. 


\section{3. 연구목적과 연구방법 및 표본}

\section{1 연구목적과 연구방법}

\subsection{1 연구목적과 연구가설}

본 연구의 질문은 ‘스팩합병 상장이 기존 일반상장과 비교할 때 유용한가?'이다. 일반상장과 유사한 기업이 스팩합병 상장을 이용한다면 새로운 상장 제도로서 의미가 퇴색될 것이다. 일반상장과 상이한 특성의 기업이 스팩합병 상장을 통해서 거래소에 진입할 수 있다면, 스팩합병 상장은 가치 있고 유용하기 때문이다. 스팩합병 상장이 일반상장과는 차별화된 기업의 거래소시장 진입을 제공하는 유의미한 실증결과가 국내와 해외시장에서 이미 밝혀졌다(Cha et al., 2019; Hong and Yang, 2021; Datar et al., 2012; Dimitrova, 2017; Kolb and Tykvova, 2016). 스팩합병 상장의 유용성 조사에 필수적이므로 본 연구 또한 이를 재검증하며, 첫 번째 가설은 다음과 같다.

가설 1: 스팩합병 상장과 일반상장의 기업특성은 차이가 있다.

스팩합병 상장이 일반상장과 차별되는 코스닥시장 진입 경로를 제공하더라도 상장이후 기업이 성장하지 않고 부실화된다면, 우회상장처럼 주식시장에 대한 부정적 효과로 인해 의미가 퇴색될 것이다. 스팩합병 상장의 장기재무성과 분석이 필요한 이유이다. 스팩합병 상장이후 부정적 성과를 보고하는 해외선행연구에 비해(Datar et al., 2012; Dimitrova, 2017; Kolb and Tykvova, 2016), 합병상장이후 재무성과를 분석한 국내 선행연구는 부족하다. Kim and Lee(2019)와 Kim and Kang(2019)이 스팩합병 상장이후 주가를 분석했지만 앞서 설명했듯이 추가분석이 요구되며, 영업성과를 측정한 연구는 확인되지 않는다. 스팩합병 상장의 부정적 결과가 일반 상장과 다른 절차와 규정 등에 기인하겠지만 해외선행연구가 대부분이며, 국내주식시장은 해외주식시장과 상이한 결과가 초래될 수도 있겠다. 스팩 경영진의 도덕적 해이를 방지하고 우량기업 합병추진 유인이 존재하기 때문에, 스팩합병 상장성과가 일반상장보다 열등하지 않을 가능성을 부인할 수 없다. 구체적으로, 스팩 발기인 소유지분의 매각제한규정은 이들의 보상이 합병기업의 합병이후 성과에 연결되어, 스팩 경영진은 우량한 중소기업을 상장시킬 유인이 높으며 비상장기업을 고평가할 유인이 낮게 된다(Kang and Kim, 2018). 거래소의 합병상장심사 승인 통과 이후 최종합병결의를 위한 주주총회에서도, 발기인의 의결권 행사는 제한되어 일반주주의 의사로 합병이 결정된다. 거래소의 합병심사 또한 일반상장과 유사한 기준이 적용되고 있어, 상장이후 성과가 일반상장보다 악화되지 않을 수 있다.

스팩합병 상장기업의 장기재무성과에 대한 분석이 선행되어야 스팩합병의 유용성을 제대로 평가할 수 있겠다. 해외 선행연구와 동일하게 스팩합병 상장이 일반상장보다 열등한 재무성과가 나타난다면(Datar et al., 2012; Dimitrova, 2017; Kolb and Tykvova, 2016) 이를 방지하기 위한 정책수립이 필요하며, 그렇지 않다면 스팩합병 상장은 새로운 코스닥진입 수단으로써 유용성이 입증된다. 두 번째 가설은 스팩합병 상장의 재무성과에 관한 내용이며 다음과 같이 표현된다.

가설 2: 스팩합병 상장의 장기재무성과는 일반상장보다 열등하지 않다. 


\subsection{2 장기재무성과 측정}

스팩합병 상장기업의 장기재무성과는 주식성과와 영업성과로 측정된다. 먼저 장기주식성과 측정에 필수적인 측정기준일을 선택해야 한다. 스팩합병은 합병공시일, 합병기일, 상장일 등의 다양한 사건일이 존재한다. 합병기업의 장기주식성과를 측정하는 연구들은 합병기일과 상장일을 기준일로 설정한다. 본 연구는 일반상장기업을 대응집단으로 사용하기 때문에 상장일을 사건일로 간주하여 장기주식성과를 계산한다.

Ritter(1991)는 IPO 기업의 장기주식성과를 보유수익률(BHR)로 측정하고 벤치마크포트 폴리오와 비교한다. Ihm(1997)도 Ritter(1991)의 방법을 채택하여 IPO 기업의 보유수익률과 주가지수의 보유수익률을 비교한다. 나스닥기업의 주가자료 분석은 시장조정 수익률이 적합 하다는 Campbell and Wasley(1985)연구에 근거하여 Oh and Han(2014)은 IPO 기업 보유수익률에서 코스닥시장지수 보유수익률을 차감한 보유초과수익률(BHAR)을 사용한다. 본 연구 또한 이들의 방법을 준용하여 코스닥시장지수 수익률을 차감한 장기 보유초과수익률을 사용한다.7) 합병기업의 장기주식성과 또한 보유초과수익률이 많이 적용되며(Jung and Park, 1999; Kang and Kim, 2009), 특히 Kolb and Tykvova(2016)는 스팩합병의 장기성과측정에 보유초과수익률을 사용한다. 보유초과수익률은 다음의 과정으로 계산된다. 먼저, 스팩합병 상장기업과 일반상장기업의 월별수익률을 이용하며 사건일 다음 월 $(+1 \mathrm{M})$ 부터 12 개월, 24 개월, 36 개월 기간까지 보유수익률을 계산한다. 벤치마크로 사용되는 코스닥시장지수 또한 동일기간 보유수익률이 측정된다. 다음으로 상장기업의 보유수익률 $\left(\mathrm{BHR}_{\mathrm{frm}}\right)$ 에서 코스닥지수 보유수익률 $\left(\mathrm{BHR}_{\mathrm{KOSDAQ}}\right)$ 을 차감하여 보유초과수익률 $(\mathrm{BHAR})$ 이 계산되며 아래의 식과 같다.

$$
\mathrm{BHAR}=\mathrm{BHR}_{\mathrm{firm}}-\mathrm{BHR}_{\mathrm{KOSDAQ}}
$$

회계이익을 이용한 영업성과측정은 이익조정에서 자유로울 수 없다. IPO기업의 이익조정은 널리 보고된 현상이며(Aharony et al., 1993; Friedlan, 1994; Teoh et al., 1998), 국내 코스닥 신규등록기업의 이익조정현상도 이미 밝혀진 사실이다(Choi et al., 2010; Lee et al., 2005).8) 기업 간 합병에서도 회계이익은 합병비율 결정에 중요한 요인이므로, 합병기업은 이익을 상향조정한다(Erickson and Wang, 1999; Louis, 2004). 피합병기업의 이익조정현상이 발견되지 않은 Erickson and Wang(1999)과 상이하게, Jeong and Bae(2006)는 피합병법인이 관계사가 아니면 합병법인과 피합병법인 모두 이익을 상향하는 결과를 발견한다.9) 스팩합병 상장 또한

7) Barber and Lyon(1997)에 의하면 보유초과수익률(BHAR)을 이용한 장기주가성과 측정이 누적초과 수익률 $(\mathrm{CAR})$ 보다 모형의 검정력을 높일 수 있다.

8) 해외연구가 IPO 전후 이익조정현상을 모두 보고하는 반면에 국내 연구의 유가증권시장 기업과 코스닥시장 이익조정현상이 상이한 점이 이채롭다. 유가증권기업은 상장연도와 상장이후 연도에 이익을 상향조정하는 반면에(Choi, 2006; Choi and Kim, 1997; Kim et al., 2004) 코스닥시장 기업은 상장직전과 상장연도에 이익조정현상이 관측된다(Choi et al., 2010; Lee et al., 2005).

9) Erickson and Wang(1999)은 합병기업과 달리 피합병기업의 이익조정현상을 발견하지 못한다. 피합병기업은 합병기업보다 합병결정까지 이익조정할 시간이 충분하지 않기 때문이라고 설명한다. 반면에 Jeong and Bae(2006)는 관계사가 아닌 합병에서 두 법인의 이익조정을 발견한다. 저자들은 
스팩과 비상장 피합병법인의 합병이고 스팩법인 발기인의 이해관계 회사와 합병이 불가능하기 때문에, Jeong and Bae(2006)의 주장처럼 피합병법인의 이익조정이 가능할 수 있다. 실제로 Min and Cha(2017)는 스팩합병 상장기업의 상장 직전년도 회계이익 상향조정을 발견한다.

이익조정에 의한 영업성과 왜곡을 최소화하기 위해서는 현금흐름 성과지표 사용이 타당하다. 본 연구는 선행연구를 참고하여 $\mathrm{EBITDA}$ 와 영업현금흐름 $(\mathrm{CFO})$ 을 채택하며, 각각 $\mathrm{EBITDA}$ 와 $\mathrm{CFO}$ 를 총자산으로 나눈 수치를 사용한다.10)

합병의 영업성과 측정은 인수기업의 영업성과변화를 이용한다. 인수기업이 합병의 주체이면서 합병이후 생존 기업이기 때문이다. 반면 스팩은 합병 주체이지만 합병을 위한 명목회사에 불과하고 합병이후 생존 기업은 피합병 기업이다. 스팩합병 상장기업의 영업성과측정은 피합병기업의 영업성과를 사용해야 한다. 즉, 합병 이전의 피합병기업의 영업성과 $(\mathrm{OP})$ 와 합병이후 합병기업의 영업성과를 사용하여 다음과 같이 계산된다.

$$
\mathrm{dOP}(\mathrm{a}, \mathrm{b}) \text { = 합병기업의 } \mathrm{OP}(\mathrm{b}) \text { - 피합병 비상장기업의 } \mathrm{OP}(\mathrm{a}) 11)
$$

$\mathrm{a}$ 는 합병이전 연도이며 $\mathrm{b}$ 는 합병이후 연도를 의미한다. 국내 선행연구를 살펴보면 대응기업대비 초과영업이익으로 합병의 영업성과를 측정한다(Jeong, 2007; Kang and Suh, 2010). 스팩합병은 합병과 $\mathrm{IPO}$ 의 성격이 혼재되어 있고 스팩합병 상장과 일반상장의 비교분석에 초점을 두기 위해서, 벤치마크 대비 계산되는 초과영업이익 대신에 일반상장기업과의 영업성과 차이를 검증한다.

\subsection{3 연구모형}

스팩합병 상장기업과 일반상장기업의 특성을 비교하여, 스팩합병 상장의 의의와 유용성을 검증한다. 이를 위해 스팩합병 상장기업은 1 의 값을 가지고 일반상장기업은 0 의 값을 가지는 $\mathrm{SPAC}$ 을 종속변수로 하는 로짓회귀분석을 실시한다.

$$
\begin{aligned}
S P A C= & \alpha+\beta_{1} S I Z E+\beta_{2} L E V+\beta_{3} C R+\beta_{4} R O A+\beta_{5} T A T O V+\beta_{6} C A S H \\
& +\beta_{7} P P E+\beta_{8} S G A+Y R+e
\end{aligned}
$$

한국의 합병은 상장회사가 비상장회사에 비공개 접촉하여 합병을 진행하고 공시하기 때문에 합병 법인과 피합병법인 모두 합병전에 이익조정이 가능하다고 설명한다.

10) 영업성과를 EBITDA/총자산으로 측정한 연구는 Loughran and Ritter(1997), Ihm(1997), Kang and $\operatorname{Kim}(2009)$ 등이 확인된다. 다수의 연구가 $\mathrm{EBITDA}$ 를 사용하고 있으며, 발생액의 효과를 완전히 제거하기 위해서 영업현금흐름 $(\mathrm{CFO}) /$ 총자산을 추가로 채택한다.

11) 본 연구는 스팩합병의 영업성과 $(\mathrm{OP})$ 를 합병전년도와 합병이후의 차이인 $\mathrm{dOP}(-1,+1)$ 와 $\mathrm{dOP}(-1,+2)$ 로 측정하며, 0 은 합병연도를 의미한다. 추가로 $\mathrm{dOP}(-1,+1)$ 를 $\mathrm{dOP}(-1,0)$ 과 $\mathrm{dOP}(0,+1)$ 로 분해한다. 이때 $\mathrm{dOP}(0,+1)$ 는 합병이후의 수치이므로 합병기업의 $\mathrm{OP}$ 가 사용된다. $\mathrm{dOP}(-1,+2)$ 또한 $\mathrm{dOP}(-1,0)$ 과 $\mathrm{dOP}(0,+2)$ 로 분해되며 $\mathrm{dOP}(0,+2)$ 는 합병기업의 $\mathrm{OP}$ 로 측정된다. $\mathrm{dOP}(0,+1)$ 와 $\mathrm{dOP}(0,+2)$ 는 합병 기일에 따라서 합병성과로 간주되기 어렵다. 예를 들어 연초 합병이 완료된 스팩합병 상장의 경우, 합병성과가 아닌 합병이후 성과에 더 적합하기 때문이다. 이는 $\mathrm{dOP}(-1,0)$ 에서도 마찬가지이다. 따라서 합병성과는 $\mathrm{dOP}(-1,+1)$ 와 $\mathrm{dOP}(-1,+2)$ 로 측정되며, 합병기일기점으로 분해된 영업성과는 추세 판단에 이용된다. 이점을 지적해 주신 심사자님께 감사드립니다. 
기업특성 변수는 우회상장과 일반상장기업을 비교·분석한 Kim et al.(2014)을 참고하여 선정 한다.12) 기업규모(SIZE)는 정보의 비대칭성과 규모위험 등을 대리하는 변수이며, 자산총계에 자연로그를 취한 값이다. 기업의 대표적인 재무비율인 안정성비율, 수익성비율, 활동성비율, 성장성비율을 독립변수로 사용한다. 먼저, 안정성비율은 부채비율(LEV)로 측정되며, 부채총계를 자산총계로 나눈 값이다. 단기안정성을 측정하는 유동비율 $(\mathrm{CR})$ 을 추가하여 장단기 안정성비율을 모두 포함한다. 유동비율은 유동자산을 유동부채로 나눈 값이다. 수익성의 경우 당기순이익을 자산총계로 나눈 총자산순이익률(ROA)을 채택한다. 총자산회전율(TATOV)은 활동성을 나타내는 변수이며, 매출액을 자산총계로 나누어 계산된다.

현금성자산(CASH)은 현금및현금성자산을 총자산으로 나눈 수치이다. 유형자산(PPE)과 판매관리비(SGA)는 각각 유형자산과 판매 및 관리비를 총자산으로 나누어 계산된다. 연도더미 변수(YR) 또한 통제변수로써 회귀모형에 포함된다.

스팩합병 상장의 장기재무성과는 다음의 회귀분석을 통해 일반상장과 비교하게 된다.

$$
\begin{aligned}
d O P \text { or } B H A R= & \alpha+\beta_{1} S P A C+\beta_{2} S I Z E+\beta_{3} L E V+\beta_{4} C R+\beta_{5} R O A \\
& +\beta_{6} T A T O V+\beta_{7} C A S H+\beta_{8} P P E+\beta_{9} S G A+Y R+e
\end{aligned}
$$

종속변수로 사용되는 재무성과는 앞서 설명한 영업성과변화(dOP)와 보유초과수익률(BHAR) 이다. 스팩합병 상장과 일반상장의 재무성과 차이는 스팩더미변수(SPAC)로 검증된다. 스팩합병 상장기업의 재무성과가 일반상장기업보다 열등하다면 스팩더미변수는 음(-)의 수치가 기대되며, 반대로 스팩합병 상장성과가 일반상장보다 우수하다면 양 $(+)$ 의 값이 예상된다. 앞의 로짓회귀 분석에 사용된 변수들이 통제변수로써 회귀모형에 모두 포함된다.

\section{2 표본선정}

스팩 합병상장의 유용성 검증이 연구의 목적이므로 합병에 성공한 스팩이 분석대상이다. 스팩 도입 시점부터 2017년까지 합병에 성공한 스팩 자료를 수집하고, 합병이후 상장기업의 재무자료가 존재하지 않은 스팩합병을 제외한다. 그 결과 최종적으로 57 개 스팩합병이 분석에 이용된다.

스팩상장은 코스닥시장에서 거의 이루어지며, 실제로 합병에 성공한 57 개 스팩 모두 코스닥 시장에 상장되어 있다. 따라서 동일기간 코스닥시장 상장기업을 대응기업으로 선정한다. 표본 기간 코스닥시장 상장기업에서 기술성장기업 상장 특례기업과 재무제표 정보가 누락된 기업을

12) 일반상장기업과 스팩합병 상장기업의 차별성 검증이 본 연구의 목적이다. 스팩경영진의 비상장법인 선택요인을 탐색하기 위해서 일반상장기업과의 차이를 분석한다. 스팩합병 상장과 일반상장을 분석한 Hong and Yang(2021)의 연구모형이 있지만, 이들이 사용한 공모과정변수(증권사, 상장처리기간, 공모비율)는 스팩경영진의 피합병법인 선택 시점에 고려 불가능하므로 본 연구에 적합하지 않다. Hong and Yang(2021)보다 다양한 기업의 재무특성을 사용한 Kim et al.(2014)의 연구모형 적용이 타당하다고 판단된다. 
제외한 280건이다. 13$)$

<표 2>는 스팩합병 상장기업과 일반상장기업의 연도별 건수를 보여준다. 일반상장기업은 상장일 이전 거래소를 통한 주식거래가 불가능하지만, 스팩합병 상장의 경우 신주상장일 이전에도 스팩 거래는 지속된다. 스팩과 피합병 기업의 합병이 완료되는 시점인 합병기일을 사용하여 연도별 분포를 작성한다.

〈표 2〉스팩합병 상장과 일반상장의 연도별 분포

이 표는 코스닥시장에 스팩합병으로 상장한 기업(스팩합병 상장기업)과 일반적인 절차를 거쳐 상장한 기업(일반상장기업)의 연도별 및 업종별 분포를 보여준다.

Panel A: 연도별 분포

\begin{tabular}{|c|c|c|c|c|}
\hline & \multicolumn{2}{|c|}{ 스팩합병 상장 } & \multicolumn{2}{|c|}{ 일반상장 } \\
\hline & 빈도 & 백분율(\%) & 빈도 & 백분율(\%) \\
\hline 2011 & 2 & 3.51 & 53 & 18.93 \\
\hline 2012 & 4 & 7.02 & 21 & 7.50 \\
\hline 2013 & 4 & 7.02 & 31 & 11.07 \\
\hline 2014 & 1 & 1.75 & 38 & 13.57 \\
\hline 2015 & 13 & 22.81 & 44 & 15.71 \\
\hline 2016 & 12 & 21.05 & 44 & 15.71 \\
\hline 2017 & 21 & 36.84 & 49 & 17.50 \\
\hline 합계 & 57 & 100 & 280 & 100 \\
\hline
\end{tabular}

Panel B: 업종별 분포

\begin{tabular}{lrrrrr}
\hline & 빈도 & 백분율(\%) & & 빈도 & 백분율(\%) \\
\cline { 1 - 2 } \cline { 5 - 5 } 제조업 & 29 & 50.88 & & 199 & 71.07 \\
하수·폐기물 처리, 원료재생 및 환경복 & 0 & 0.00 & & 1 & 0.36 \\
건설업 & 1 & 1.75 & 2 & 0.71 \\
도매 및 소매업 & 3 & 5.26 & 13 & 4.64 \\
숙박 및 음식점업 & 1 & 1.75 & & 0 & 0.00 \\
출판, 영상, 방송통신 및 정보서비스업 & 18 & 31.58 & & 40 & 14.29 \\
금융 및 보험업 & 1 & 1.75 & 0 & 0.00 \\
전문, 과학 및 기술 서비스업 & 3 & 5.26 & 21 & 7.50 \\
사업시설관리 및 사업지원 서비스업 & 0 & 0.00 & 1 & 0.36 \\
교육 서비스업 & 0 & 0.00 & 2 & 0.71 \\
예술, 스포츠 및 여가관련 서비스업 & 1 & 1.75 & 1 & 0.36 \\
\hline 합계 & 57 & 100 & 280 & 100 \\
\hline
\end{tabular}

스팩 도입부터 2014년까지 연도별 합병 건수가 4건 이하에 불과하지만, 2015년부터 연도별 합병 건수가 급증한다. 첫 도입 이후 합병기업 탐색에 소요되는 시간의 영향도 있겠다. 코스닥시장 일반상장기업 건수와 비교하면 스팩합병 상장의 비율 증가추세가 확연하다. 2017년 스팩합병

13) 2005년 3월부터 시행된 코스닥시장 특례상장제도는 기술력과 성장성이 우수한 기업에 신속한 상장기회 제공을 목적으로 하며 상장요건 또한 일반상장기업보다 완화된다. 일반상장기업과 스팩합병 상장기업의 차이점을 분석하는 연구의 목적상 특례상장기업은 일반상장기업에서 제외하는 것이 타당하다. 
Long-term Performance of Going Public through SPACs

상장은 21 건, 일반상장기업은 49 건으로, 스팩합병 상장이 일반상장의 약 $43 \%$ 수준까지 성장한다. 스팩합병 상장의 코스닥시장 진입 경로로써 정착이 확인된다.

스팩합병 상장기업과 일반상장기업의 업종별 분포를 보면, 제조업과 비제조업의 비중 차이가 확연하다. 일반상장기업은 약 $71 \%$ 가 제조업이지만, 스팩합병 상장기업의 제조업은 약 $51 \%$ 로 상대적으로 낮다. 제조업을 제외하면 두 집단 모두 출판, 영상, 방송통신 및 정보서비스업 비중이 높으며, 스팩합병 상장이 $31.58 \%$ 로 IPO 기업의 $14.29 \%$ 보다 2 배 이상 높다.

〈표 3〉스팩의 주요사건 소요기간

스팩상장일, 합병공시일, 합병기일, 신주상장일 등 주요사건 일간의 소요기간(달력일)을 제시하고 있다.

\begin{tabular}{|c|c|c|c|c|c|}
\hline & 스팩합병의 & 주요사건일 & & mean & median \\
\hline \multirow[t]{2}{*}{ 스팩상장일 } & 합병공시일 & & & 409.9649 & 378 \\
\hline & 합병공시일 & 합병기일 & & 167.3509 & 158 \\
\hline \multirow[t]{2}{*}{ 스팩상장일 } & & 합병기일 & & 577.3158 & 547 \\
\hline & & 합병기일 & 신주상장일 & 15.0877 & 15 \\
\hline
\end{tabular}

스팩 경영진이 합병대상을 탐색하고 합병이 완료되는 시점까지 주요 사건일은 스팩상장일, 합병공시일, 합병기일, 신주상장일 등이다. 합병공시일은 비상장법인과의 합병을 공시한 날을, 합병기일은 스팩과 피합병기업의 합병이 완료되는 날을, 신주상장일은 합병과정 발행된 신주가 거래소에 상장되는 날을 의미한다. <표 3>은 주요 사건일간의 달력일을 보여준다.14)

스팩상장 이후 합병공시일까지 약 410 일이 소요되며, 합병 공시 이후 약 167 일 이후 합병이 완료된다. 합병기일부터 약 15 일 이후 신주가 거래소에 상장된다. 스팩상장에서 합병 완료까지 577일 소요되고 있어, 2년 이내 비상장기업 탐색에서 합병까지 완료된다.

<표 4>는 스팩의 공모정보와 합병정보를 보여준다.15) 스팩의 공모정보는 공모가격(PRICE_IPO), 공모주식수(NS_IPO), 공모금액(AMT_IPO), 청약경쟁률(CPR_IPO), 기관투자자배정비율 (ALLC_INST) 등이다. 스팩의 공모가격 평균(중앙값)은 2219(2000)원으로 IPO 기업의 공모 가격보다는 낮다. 기관투자자배정비율이 약 $72 \%$ 로 상당히 높아 기관투자자가 스팩 공모를 주도한다.

스팩합병 공시정보로부터 합병 직전 스팩의 재무정보와 합병 관련 정보를 확인할 수 있다. 합병비율(MR)은 피합병법인 1주에 대한 합병법인 스팩이 교부해야 하는 주식수를 의미한다. 합병비율의 평균값은 약 51이지만 중앙값은 약 9주에 불과하며 최대값은 약 801주로 상당한 양(+)의 극단치가 확인된다. 합병직전 스팩 자산의 대부분은 유동자산(CA_SP)이며 부채비율 (LEV_SP)이 매우 낮은데, 합병목적의 명목회사라는 스팩의 특성과 의무예치조항에 의한 자연스러운 결과이다.

14) 합병 공시 이후 피합병 비상장법인의 상장적격성 심사 기간 스팩의 매매가 일시중지되었다가 거래가 재개되므로 영업일은 매매중지 기간만큼 감소한다.

15) 스팩의 상장정보는 pstock.co.kr 사이트에서, 합병 직전 스팩의 재무제표와 합병정보는 금융감독원 공시사이트(dart.fss.or.kr)로부터 수집하였다. 
〈표 4>스팩의 특성

스팩의 상장공모정보(패널A)와 합병정보(패널B)를 제시한다. 패널 A는 공모가격(PRICE_IPO), 공모주식수 (NS_IPO), 공모금액(AMT_IPO), 청약경쟁률(CPR_IPO), 기관투자자배정비율(ALLC_INST) 등의 스팩의 상장정보를 보여준다. 패널 $\mathrm{B}$ 는 합병직전 스팩의 재무정보와 합병비율 $(\mathrm{MR})$ 을 보여주며, 금융감독원 공시자료에서 확인된다. 유동자산(CA_SP), 비유동자산(NCA_SP), 유동부채(CL_SP), 비유동부채(NCL_SP), 자본(EQUITY_SP)은 총자산(TA_SP)으로 나눈 수치이다. 부채비율(LVE_SP)은 부채를 총자산으로 나눈 값이며, 합병비율(MR)은 피합병법인 1주에 대한 합병법인 스팩이 교부해야 하는 주식수를 의미한다.

Panel A: 공모정보

\begin{tabular}{lrrrrr}
\hline & \multicolumn{1}{c}{ mean } & median & \multicolumn{1}{c}{$\max$} & \multicolumn{1}{c}{$\min$} & \multicolumn{1}{c}{ std } \\
\hline PRICE_IPO(원) & 2219.2980 & 2000.0000 & 6000.0000 & 1000.0000 & 796.2947 \\
NS_IPO(천주) & 6102.6580 & 5337.5000 & 19700.0000 & 1750.0000 & 3077.2470 \\
AMT_IPO(천원) & 13190158 & 12000000 & 37500000 & 3500000 & 6718490 \\
CPR_IPO & 125.4575 & 36.1100 & 540.0000 & 0.0300 & 148.6603 \\
ALLC_INST & 0.7204 & 0.7500 & 0.8000 & 0.4000 & 0.1010 \\
\hline Panel B: 합병정보 & & & & \\
\hline & mean & median & max & min & std \\
\hline CA_SP & 0.9265 & 1.0000 & 1.0000 & 0.1274 & 0.2392 \\
NCA_SP & 0.0734 & 0.0000 & 0.8692 & 0.0000 & 0.2390 \\
CL_SP & 0.0080 & 0.0003 & 0.2561 & 0.0000 & 0.0357 \\
NCL_SP & 0.0997 & 0.0998 & 0.1906 & 0.0000 & 0.0405 \\
LEV_SP & 0.1077 & 0.1009 & 0.2607 & 0.0459 & 0.0385 \\
EQUITY_SP & 0.8923 & 0.8990 & 0.9541 & 0.7393 & 0.0385 \\
TA_SP(천원) & 15541000 & 13139000 & 42564000 & 3992000 & 8096398 \\
MR & 51.3728 & 9.1996 & 801.3545 & 0.4410 & 126.3407 \\
\hline
\end{tabular}

\section{4. 실증결과}

\section{1 기술적 통계량}

스팩합병 상장기업과 일반상장기업의 기술적 통계량과 차이분석은 <표 $5>$ 로 정리된다. 스팩합병 상장기업이 일반상장기업보다 기업규모가 작고, 유형자산 비중은 낮고, 판관비는 높다. 정보비대칭성이 높은 소규모 기업의 상장기회를 제공한다는 점에서 스팩합병의 유용성이 확인 된다. <표 2>의 업종별 분포로부터 스팩합병의 일반상장보다 비제조업 비율이 높은 결과는 일반상장기업 대비 낮은 유형자산과 판관비와 연결 선상에 있겠다.

스팩합병 상장의 비제조업에 대한 유용성을 규명하기 위해서 비제조업과 제조업을 구분하여 두 집단의 차이를 분석한다. 제조업종 기업의 경우 스팩합병상장과 일반상장의 차이가 없는 반면에, 비제조업은 전체표본의 차이와 유사하다. 즉, 전체표본의 결과는 비제조업의 결과에 기인한다. 비제조업종에서 밝혀진 스팩합병 상장과 일반상장의 유의한 차이는 스팩합병 상장의 비제조업 상장에 대한 유의미한 역할을 지지하는 결과로 해석할 수 있다. 
Long-term Performance of Going Public through SPACs

스팩합병 상장과 일반상장기업의 업종별 분포와 재무특성 비교분석결과는 다음과 같이 요약된다. 스팩합병 상장은 기존 $\mathrm{IPO}$ 에 의한 코스닥시장 상장을 보완하는 점에서 가치가 있다.

〈표 5〉스팩합병 상장과 일반상장의 특성: 차이분석

스팩합병 상장기업과 일반상장기업 변수들의 평균값과 중앙값을 제시하고, 두 집단 간의 차이분석 결과를 보여준다. 기업규모(SIZE)는 자산총계에 자연로그를 취한 값이며, 부채비율(LEV)은 부채총계를 자산 총계로 나눈 값이다. 유동성비율 $(\mathrm{CR})$ 은 유동자산을 유동부채로 정의된다. 총자산순이익률 $(\mathrm{ROA})$ 은 당기순이익을 자산총계로 나누어 계산한다. 총자산회전율(TATOV)은 매출액을 총자산으로 나눈 값이다. 현금성자산(CASH)은 현금및현금성자산을 총자산으로 나누어 계산된다. 유형자산(PPE)은 유형자산을 총자산으로 나눈 수치이며, 판매관리비(SGA)는 판매 및 관리비를 총자산으로 나눈 값이다. 모든 변수는 코스닥시장 상장직전 회계년도 말 기준으로 측정된다. ${ }^{* * *},{ }^{* *},{ }^{*}$,는 각각 $1 \%, 5 \%, 10 \%$ 수준에서 통계적으로 유의함을 나타낸다.

\begin{tabular}{|c|c|c|c|c|c|c|}
\hline & \multicolumn{2}{|c|}{ 스팩합병 상장기업(A) } & \multicolumn{2}{|c|}{ 일반상장기업(B) } & \multicolumn{2}{|c|}{$\mathrm{A}-\mathrm{B}$} \\
\hline & mean & median & mean & median & $\mathrm{t}-$ stat. & $z^{-}$stat. \\
\hline \multicolumn{7}{|c|}{ 전체표본: $\mathrm{N}(\mathrm{A})=57, \mathrm{~N}(\mathrm{~B})=280$} \\
\hline $\begin{array}{l}\text { SIZE } \\
\end{array}$ & 17.2405 & 17.0931 & 17.7472 & 17.6414 & $-4.15^{* * *}$ & $-4.14^{* * *}$ \\
\hline LEV & 0.4239 & 0.4000 & 0.4633 & 0.4669 & -1.40 & -1.40 \\
\hline $\mathrm{CR}$ & 2.9666 & 2.4330 & 2.5191 & 1.7673 & 1.04 & $1.99^{* *}$ \\
\hline ROA & 0.1601 & 0.1111 & 0.1502 & 0.1303 & 0.50 & -0.58 \\
\hline TATOV & 1.1148 & 1.0650 & 1.1430 & 1.0363 & -0.38 & -0.34 \\
\hline CASH & 0.1938 & 0.1220 & 0.1491 & 0.1185 & $1.74^{*}$ & 1.03 \\
\hline PPE & 0.2123 & 0.1589 & 0.2967 & 0.2738 & $-2.86^{* * *}$ & $-3.01^{* * *}$ \\
\hline SGA & 0.3153 & 0.2162 & 0.2070 & 0.1391 & $2.80^{* * *}$ & $3.79^{* * *}$ \\
\hline \multicolumn{7}{|c|}{ 비제조업: $\mathrm{N}(\mathrm{A})=28, \mathrm{~N}(\mathrm{~B})=81$} \\
\hline SIZE & 16.7244 & 16.6929 & 17.6655 & 17.3798 & $-5.61^{* * *}$ & $-4.56^{* * *}$ \\
\hline LEV & 0.3618 & 0.2975 & 0.4006 & 0.4052 & -0.95 & -0.95 \\
\hline $\mathrm{CR}$ & 3.9709 & 3.2636 & 3.4412 & 1.9750 & 0.58 & $2.12^{* *}$ \\
\hline ROA & 0.2071 & 0.1516 & 0.1715 & 0.1386 & 1.02 & 0.54 \\
\hline TATOV & 1.2175 & 1.1974 & 1.0810 & 0.9596 & 1.06 & 1.15 \\
\hline CASH & 0.2679 & 0.2004 & 0.2050 & 0.1834 & 1.43 & 1.13 \\
\hline PPE & 0.1004 & 0.0459 & 0.1783 & 0.1007 & $-2.31^{* *}$ & -1.63 \\
\hline SGA & 0.4581 & 0.3562 & 0.3102 & 0.2253 & $2.18^{* *}$ & $3.00^{* * *}$ \\
\hline \multicolumn{7}{|c|}{ 제조업: $\mathrm{N}(\mathrm{A})=29, \mathrm{~N}(\mathrm{~B})=199$} \\
\hline $\begin{array}{l}\text { SIZE } \\
\end{array}$ & 17.7387 & 17.6710 & 17.7805 & 17.6679 & -0.30 & -0.33 \\
\hline LEV & 0.4839 & 0.4977 & 0.4888 & 0.4996 & -0.13 & -0.05 \\
\hline $\mathrm{CR}$ & 1.9969 & 1.5861 & 2.1437 & 1.5199 & -0.48 & -0.33 \\
\hline $\mathrm{ROA}$ & 0.1146 & 0.0792 & 0.1415 & 0.1174 & -1.51 & $-2.05^{* *}$ \\
\hline TATOV & 1.0156 & 0.9484 & 1.1682 & 1.0581 & -1.62 & -1.43 \\
\hline CASH & 0.1223 & 0.0962 & 0.1264 & 0.1021 & -0.19 & -0.43 \\
\hline PPE & 0.3204 & 0.3230 & 0.3449 & 0.3278 & -0.67 & -0.86 \\
\hline SGA & 0.1775 & 0.1401 & 0.1650 & 0.1240 & 0.41 & 0.89 \\
\hline
\end{tabular}




\section{2 스팩합병과 일반상장기업의 특성}

스팩합병 상장기업과 일반상장기업의 특성 차이를 파악하고자 로짓회귀분석을 실시한다.16) <표 6>의 모든 회귀분석결과에서 기업규모변수는 유의한 음(-)의 계수이다. 앞절의 차이분석 결과와 일치하며, 소규모기업은 일반상장보다는 스팩합병에 의해 상장된다. 유형자산과 판관비 변수가 포함된 모형 (2)와 (4)의 결과를 살펴보면 유의했던 차이 분석결과와는 다르게 두 변수가 유의하지 않는다. 기업규모가 유형자산과 판관비의 설명력을 압도한 결과로 유추된다.

\section{〈표 6〉스팩합병 상장과 일반상장의 특성: 회귀분석}

종속변수는 스팩합병 상장기업이면 1 의 값을 일반상장기업이면 0 의 값을 가진다. 제조업더미변수(MNF)는 제조업이면 1 의 값을 나머지는 0 의 값을 가진다. 나머지 재무비율 및 기업특성변수의 정의는 <표 $4>$ 에 제시되어 있다. ( )는 이분산성을 고려한 $\mathrm{Z}$ 값이며, ${ }^{* * *},{ }^{* *}$, *, 는 각각 $1 \%, 5 \%, 10 \%$ 수준에서 통계적으로 유의함을 나타낸다.

\begin{tabular}{lcccc}
\hline 종속변수: & & & \\
스팩합병=1, 일반상장=0 & $(1)$ & $(2)$ & $(3)$ & $(4)$ \\
\hline SIZE & $-1.061^{* * * *}$ & $-0.912^{* * *}$ & $-0.957^{* * *}$ & $-0.877^{* * *}$ \\
& $(-3.646)$ & $(-3.155)$ & $(-3.442)$ & $(-3.136)$ \\
LEV & -0.564 & -0.477 & -0.476 & -0.439 \\
& $(-0.483)$ & $(-0.408)$ & $(-0.411)$ & $(-0.380)$ \\
CR & -0.043 & -0.063 & -0.057 & -0.064 \\
& $(-0.816)$ & $(-0.981)$ & $(-1.081)$ & $(-1.040)$ \\
ROA & -1.237 & -1.647 & -1.360 & -1.641 \\
& $(-0.574)$ & $(-0.726)$ & $(-0.654)$ & $(-0.749)$ \\
TATOV & -0.282 & -0.489 & -0.299 & -0.460 \\
& $(-0.670)$ & $(-1.103)$ & $(-0.735)$ & $(-1.053)$ \\
CASH & & -0.108 & & -0.157 \\
& & $(-0.089)$ & & $(-0.132)$ \\
PPE & & -0.655 & & -0.328 \\
& & $(-0.666)$ & & $(-0.313)$ \\
SGA & & 1.202 & & 1.067 \\
& & $(1.493)$ & & $(1.331)$ \\
MNF & & & $-0.538^{*}$ & -0.364 \\
& & $13.662^{* * * *}$ & $(-1.745)$ & $(-1.043)$ \\
Constant & & $14.610^{* * * *}$ & $13.188^{* * *}$ \\
& & $(2.607)$ & $(2.879)$ & $(2.588)$ \\
\hline YR & $16.039^{* * * *}$ & Yes & Yes & Yes \\
N & $(3.038)$ & 337 & 337 & 337 \\
Chi ${ }^{2}$ & Yes & 33.14 & 36.32 & 35.21 \\
Pseudo R & 337 & 0.179 & 0.175 & 0.182 \\
\hline & 32.86 & &
\end{tabular}

16) 회귀분석모형에 산업더미변수를 추가해도 실증결과는 차이가 없으며 지면 관계상 결과는 생략 한다. 
<표 2>에서 확인된 스팩합병 상장과 일반상장의 업종분포 차이를 검증하기 위해서, 모형 (3)과 (4)에 제조업더미변수(MNF)를 포함한다. 제조업더미변수는 제조업이면 1 의 값을 나머지는 0 의 값을 가진다. 모형 (4)의 제조업더미변수의 계수는 유의하지 않지만, 제조업과 유형자산과 판관비의 높은 연관성이 영향을 줄 수 있다.17) 따라서 두 변수를 제외한 모형 (3)의 제조업더미변수는 $10 \%$ 유의수준이지만 통계적으로 유의하다. 스팩합병 상장은 제조업이 아닌 기업의 상장을 지원하는 긍정적인 효과가 다소 존재한다.

스팩합병과 일반상장의 비교분석 결과는 다음과 같이 정리된다. 스팩합병 상장은 일반상장과는 차별화되는 상장경로이며, 일반상장보다 규모가 작고 비제조업 기업의 상장을 지원하는 유용성이 발견된다.

\section{3 스팩합병 상장의 재무성과}

$<$ 표 7>은 스팩합병 상장기업과 일반상장기업의 상장이후 장기재무성과를 보여준다. 장기주식 성과는 스팩합병 상장과 일반상장기업 모두 상장월 기준으로 계산되며, 상장이후 12 개월 $(+1 \mathrm{M}$, $+12 \mathrm{M}), 24$ 개월 $(+1 \mathrm{M},+24 \mathrm{M}), 36$ 개월 $(+1 \mathrm{M},+36 \mathrm{M})$ BHAR이 측정된다. 18$) 19)$ 두 집단 모두 $\mathrm{BHAR}$ 의 평균값이 중앙값보다 높은 수치로 보아, 상당한 양 $(+)$ 의 극단치 존재를 파악할 수 있다. BHAR의 평균값보다 중앙값 중심의 결과해석이 적절하겠다.

일반상장기업의 보유초과수익률 중앙값은 모두 유의한 음(-)의 값으로 IPO 장기저성과현상이 관측된다. 반면 스팩합병 상장기업의 보유초과수익률은 음(-)의 수치이지만 통계적으로 유의하지 않다. 두 집단의 24 개월 보유초과수익률의 차이는 유의하지만 12 개월과 36 개월 차이는 유의하지 않다. 스팩합병 상장기업의 상장이후 장기주식성과가 일반상장기업보다 우수하다고 주장하기엔 무리가 있지만, 스팩합병 상장기업이 IPO 기업보다 열등하다는 선행연구와는 분명히 대조되는 실증결과이다. 특히 스팩합병 상장기업이 일반상장기업보다 규모가 작은 점을 고려한다면 스팩합병 상장의 주가성과의 우수성을 확인할 수 있다.

스팩합병 상장기업의 주가성과를 측정한 국내선행연구와 실증결과를 비교해 볼 수 있다. 본 연구와 표본개수가 유사한 $\operatorname{Kim}$ and $\operatorname{Kang}(2019)$ 은 상장이후 1년까지 누적초과수익률을 보고한다. 코스닥지수조정 수익률 사용은 동일하지만 음(-)의 누적평균수익률은 차이가 있다. 44 주 누적평균초과수익률은 유의하지 않다가 52 주 누적평균초과수익률이 음(-)으로 유의해지고 있어, 극단치 영향을 유추할 수 있다. 장기주가성과의 평균값만을 제시하고 있어 극단치 영향을 정확히 파악할 수는 없다.

17) 제조업 $(\mathrm{MNF})$ 과 유형자산(PPE), 제조업과 판매 및 관리비(SGA)의 스피어만 상관계수는 각각 0.46 , -0.36 으로 아주 높지는 않지만, 상관관계가 확인된다.

18) 스팩합병 상장의 장기주식성과 측정기준을 상장일 대신에 합병기일을 사용하더라도, 두 집단의 2 년 보유초과수익률의 차이분석 유의성이 사라지지만 나머지 실증결과는 동일하다.

19 ) 일반상장기업의 $\operatorname{BHAR}(+1 \mathrm{M},+36)$ 의 표본개수가 280 개가 아니고 279 개로 1 개 감소한다. 이는 2012 년 7월 26일에 상장한 우양에이치씨의 2015년 3월 17일 상장폐지 때문이다. 
〈표 7〉스팩합병 상장과 일반상장의 재무성과: 차이분석

스팩합병 상장과 일반상장의 재무성과를 보여준다. 스팩합병 상장과 일반상장기업의 장기주식성과는 상장월 기준으로 상장이후 12 개월 $(+1 \mathrm{M},+12 \mathrm{M}), 24$ 개월 $(+1 \mathrm{M},+24 \mathrm{M}), 36$ 개월 $(+1 \mathrm{M},+36 \mathrm{M})$ 보유초과수익률 (BHAR)값이며 단위는 \%이다. EBITDA는 영업이익에 감가상각비를 더하고 총자산으로 나눈 값이며, $\mathrm{CFO}$ 는 영업현금흐름를 총자산으로 나눈 수치이다. 영업성과변화(a, b)는 b년도 영업성과에서 a년도 영업성과를 차감하여 계산되며 0 은 상장연도를 의미한다. ${ }^{* * *},{ }^{* *}$, *는 각각 $1 \%, 5 \%, 10 \%$ 수준에서 통계적으로 유의함을 나타낸다.

\begin{tabular}{|c|c|c|c|c|c|c|c|c|c|}
\hline & \multicolumn{3}{|c|}{ 스팩합병 상장 $(\mathrm{A})$} & \multicolumn{3}{|c|}{ 일반상장(B) } & \multicolumn{2}{|c|}{$\mathrm{A}-\mathrm{B}$} \\
\hline & & $\mathrm{n}$ & mean & median & $\mathrm{n}$ & mean & median & t-stat. & $Z^{-}$-stat. \\
\hline \multirow{3}{*}{ BHAR } & $(+1 \mathrm{M},+12 \mathrm{M})$ & 57 & 11.9113 & -12.2961 & 280 & 2.1100 & $-14.1477^{\text {*** }}$ & 0.84 & 1.18 \\
\hline & $(+1 \mathrm{M},+24 \mathrm{M})$ & 57 & 17.0918 & -6.3048 & 280 & -6.2700 & $-24.4947^{* * *}$ & $1.71^{*}$ & $2.04^{* *}$ \\
\hline & $(+1 \mathrm{M},+36 \mathrm{M})$ & 57 & 7.1059 & -23.3941 & 279 & -5.8540 & $-35.5149^{* * *}$ & 0.84 & 1.61 \\
\hline \multirow{5}{*}{ EBITDA } & $(-1,+1)$ & 57 & $-0.1641^{* * *}$ & $-0.0989^{* * *}$ & 280 & $-0.1296^{* * *}$ & $-0.1085^{* * *}$ & -1.08 & 0.02 \\
\hline & $(-1,+2)$ & 57 & $-0.1955^{* * *}$ & $-0.1152^{* * *}$ & 280 & $-0.1603^{* * *}$ & $-0.1337^{* * *}$ & -1.01 & 0.34 \\
\hline & $(0,+1)$ & 57 & $-0.0366^{* * *}$ & $-0.0300^{* *}$ & 280 & $-0.0524^{* * *}$ & $-0.0343^{* * *}$ & 1.10 & $1.66^{*}$ \\
\hline & $(0,+2)$ & 57 & $-0.0679^{* * *}$ & $-0.0367^{* * *}$ & 280 & $-0.0830^{* * *}$ & $-0.0585^{* * *}$ & 0.76 & 1.58 \\
\hline & $(-1,0)$ & 57 & $-0.1276^{* * *}$ & $-0.0858^{* * *}$ & 280 & $-0.0772^{* * *}$ & $-0.0546^{* * *}$ & $-2.22^{* *}$ & $-2.38^{* *}$ \\
\hline \multirow{5}{*}{$\mathrm{CFO}$} & $(-1,+1)$ & 57 & $-0.1137^{* * *}$ & $-0.0523^{* * *}$ & 280 & $-0.1077^{* * *}$ & $-0.0816^{* * *}$ & -0.16 & 1.12 \\
\hline & $(-1,+2)$ & 57 & $-0.1171^{* * *}$ & $-0.0512^{* * *}$ & 280 & $-0.1043^{* * *}$ & $-0.0788^{* * *}$ & -0.34 & $1.72^{*}$ \\
\hline & $(0,+1)$ & 57 & -0.0172 & -0.0137 & 280 & $-0.0298^{* * *}$ & $-0.0268^{* * *}$ & 0.57 & 1.43 \\
\hline & $(0,+2)$ & 57 & -0.0207 & -0.0048 & 280 & $-0.0264^{* * *}$ & $-0.0299^{* * *}$ & 0.26 & 1.34 \\
\hline & $(-1,0)$ & 57 & $-0.0965^{* * *}$ & $-0.0891^{* * *}$ & 280 & $-0.0779^{* * *}$ & $-0.0572^{* * *}$ & -0.65 & -0.80 \\
\hline
\end{tabular}

Kim and Lee(2019)는 상장이후 3년까지 장기성과를 측정한 점은 본 연구와 동일하지만 스팩상장표본이 21 개에 불과하다. 이들 또한 시장지수조정 초과수익률에서는 저성과현상이 나타나지 않으며, 벤치마크포트폴리오조정 초과수익률에서만 주가성과가 악화된다. 선행연구 및 본 연구의 실증결과를 보면 스팩합병 상장기업의 장기저성과는 뚜렷하지 않아, 향후 추가적인 연구가 필요하다. 또한, 주가성과 외에 영업성과에서 장기저성과현상을 확인해 볼 필요가 있겠다.

상장 직전년도 $(-1)$ 기준으로 측정한 장기영업성과는 성과지표와 무관하게 스팩합병상장과 일반상장 모두 악화된다. 성과비교시점을 상장년도 $(0)$ 를 변경하더라도 $\operatorname{dEBITDA}(0,+1)$ 와 $\operatorname{dEBITDA}(0,+2)$ 는 두 집단 모두 동일하게 악화된다. $\mathrm{dCFO}(0,+1)$ 와 $\mathrm{dCFO}(0,+2)$ 는 두 집단의 유의성의 차이가 확인된다. 일반상장은 음(-)의 수치가 유지되는 반면에 스팩합병 상장은 음(-)의 값이지만 유의성이 사라진다. 하지만 이 경우에도 일반상장기업과의 성과 차이는 유의하지 않는다. $(-1,0)$ 의 성과 또한 두 집단의 EBITDA와 $\mathrm{CFO}$ 에서 모두 음(-)의 수치이며, 두 집단 모두 상장직전년도부터 지속적인 영업성과 악화현상이 발견된다.

일반상장기업의 영업성과와 주가성과는 모두 악화되지만, 스팩합병 상장기업은 영업성과 에서만 저성과현상이 관측된다. 두 집단의 영업성과 차이는 대부분 유의하지 않아, 일반상장과 스팩합병 상장기업이 유사한 정도의 장기저성과를 겪는다고 판단된다.

스팩합병 상장의 장기재무성과는 해외선행연구와는 상충하는 결과이다. 영업성과에서는 저성과현상이 확인되지만, 주가성과 악화는 분명하지 않다. 두 집단의 재무성과 차이분석에서도 일반상장기업 대비 스팩합병 상장기업의 성과는 열등하지 않다. 국내 스팩합병 상장 심사요건이 
Long-term Performance of Going Public through SPACs

일반상장과 거의 같으며, 스팩 경영진의 성과가 합병이후 성과와 연동되는 특성 등의 효과로 유추된다. 정보의 비대칭성이 높은 소규모기업과 비제조업 기업에 코스닥시장 상장기회를 제공하고 있어, 스팩합병은 일반상장과 차별화된 상장경로로서 가치와 유용성이 존재한다.

두 집단의 장기재무성과를 검증하는 회귀분석결과는 <표 8>이다. 주가성과는 상장이후 12 개월, 24 개월, 36 개월 $\operatorname{BHAR}$ 를 사용하고, 영업성과는 $\operatorname{dEBITDA}(-1,+1), \operatorname{dEBITDA}(-1$, +2 )과 동일관측 기간의 $\mathrm{dCFO}$ 이다.

〈표 8〉스팩합병 상장과 일반상장의 재무성과: 회귀분석

재무성과 측정치 $\mathrm{dEBITDA}(-1,+1), \operatorname{dEBITDA}(-1,+2), \mathrm{dCFO}(-1,+1), \mathrm{dCFO}(-1,+2), \mathrm{BHAR}(+1 \mathrm{M}$, $+12 \mathrm{M}), \mathrm{BHAR}(+1 \mathrm{M},+24 \mathrm{M}), \mathrm{BHAR}(+1 \mathrm{M},+36 \mathrm{M})$ 이 종속변수이다. 재무성과변수의 설명은 <표 $7>$ 에 기술되어 있다. SPAC은 스팩합병 상장기업이면 1 의 값을 일반상장기업이면 0 의 값을 가지는 더미변수이다. 나머지 변수에 대한 설명은 <표 $5>$ 에 기술되어 있다. ( )은 이분산성을 고려한 t값이며, ${ }^{* * *},{ }^{* *},{ }^{*}$ 는 각각 $1 \%, 5 \%, 10 \%$ 수준에서 통계적으로 유의함을 나타낸다.

\begin{tabular}{|c|c|c|c|c|c|c|c|}
\hline & $\begin{array}{c}(1) \\
\text { dEBITDA } \\
(-1,+1) \\
\end{array}$ & $\begin{array}{c}(2) \\
\text { dEBITDA } \\
(-1,+2) \\
\end{array}$ & $\begin{array}{c}(3) \\
\mathrm{dCFO} \\
(-1,+1) \\
\end{array}$ & $\begin{array}{c}(4) \\
\mathrm{dCFO} \\
(-1,+2) \\
\end{array}$ & $\begin{array}{c}(5) \\
\text { BHAR } \\
(+1 \mathrm{M},+12 \mathrm{M}) \\
\end{array}$ & $\begin{array}{c}(6) \\
\text { BHAR } \\
(+1 \mathrm{M},+24 \mathrm{M}) \\
\end{array}$ & $\begin{array}{c}(7) \\
\text { BHAR } \\
(+1 \mathrm{M},+36) \\
\end{array}$ \\
\hline SPAC & $\begin{array}{l}-0.021 \\
(-1.01)\end{array}$ & $\begin{array}{l}-0.015 \\
(-0.72)\end{array}$ & $\begin{array}{l}0.003 \\
(0.12)\end{array}$ & $\begin{array}{r}-0.008 \\
(-0.29)\end{array}$ & $\begin{array}{l}4.170 \\
(0.37)\end{array}$ & $\begin{array}{r}19.083 \\
(1.38)\end{array}$ & $\begin{array}{l}5.474 \\
(0.32)\end{array}$ \\
\hline SIZE & $\begin{array}{l}0.019^{* *} \\
(2.53)\end{array}$ & $\begin{array}{l}0.022^{* * *} \\
(2.93)\end{array}$ & $\begin{array}{l}-0.005 \\
(-0.45)\end{array}$ & $\begin{array}{c}-0.009 \\
(-0.90)\end{array}$ & $\begin{array}{l}0.996 \\
(0.16)\end{array}$ & $\begin{array}{l}-8.480^{*} \\
(-1.79)\end{array}$ & $\begin{array}{l}-8.081 \\
(-1.06)\end{array}$ \\
\hline LEV & $\begin{array}{l}-0.176^{* * *} \\
(-3.23)\end{array}$ & $\begin{array}{l}-0.206^{* * *} \\
(-3.78)\end{array}$ & $\begin{array}{l}-0.182^{* * *} \\
(-2.80)\end{array}$ & $\begin{array}{l}-0.141^{* *} \\
(-2.15)\end{array}$ & $\begin{array}{r}16.681 \\
(0.46)\end{array}$ & $\begin{array}{r}-21.710 \\
(-0.73)\end{array}$ & $\begin{array}{r}-44.775 \\
(-0.94)\end{array}$ \\
\hline $\mathrm{CR}$ & $\begin{array}{l}-0.003^{*} \\
(-1.83)\end{array}$ & $\begin{array}{l}-0.002 \\
(-1.26)\end{array}$ & $\begin{array}{l}-0.001 \\
(-0.51)\end{array}$ & $\begin{array}{l}-0.000 \\
(-0.17)\end{array}$ & $\begin{array}{l}-2.405 \\
(-1.48)\end{array}$ & $\begin{array}{l}-3.512^{* *} \\
(-2.22)\end{array}$ & $\begin{array}{l}-2.818 \\
(-1.29)\end{array}$ \\
\hline ROA & $\begin{array}{l}-1.070^{* * *} \\
(-7.26)\end{array}$ & $\begin{array}{l}-1.176^{* * *} \\
(-8.71)\end{array}$ & $\begin{array}{l}-1.044^{* * *} \\
(-5.57)\end{array}$ & $\begin{array}{l}-0.939^{* * *} \\
(-6.86)\end{array}$ & $\begin{array}{c}-41.104 \\
(-0.95)\end{array}$ & $\begin{array}{r}-30.497 \\
(-0.65)\end{array}$ & $\begin{array}{c}-143.877^{* * *} \\
(-2.90)\end{array}$ \\
\hline TATOV & $\begin{array}{l}-0.009 \\
(-0.67)\end{array}$ & $\begin{array}{r}0.007 \\
(0.48)\end{array}$ & $\begin{array}{l}0.006 \\
(0.33)\end{array}$ & $\begin{array}{c}0.029 \\
(1.56)\end{array}$ & $\begin{array}{c}-15.4366^{* *} \\
(-1.98)\end{array}$ & $\begin{array}{c}-16.384^{*} \\
(-1.67)\end{array}$ & $\begin{array}{r}-15.819 \\
(-1.45)\end{array}$ \\
\hline $\mathrm{CASH}$ & $\begin{array}{l}-0.022 \\
(-0.30)\end{array}$ & $\begin{array}{l}-0.037 \\
(-0.47)\end{array}$ & $\begin{array}{c}-0.188^{*} \\
(-1.86)\end{array}$ & $\begin{array}{l}-0.278^{* * *} \\
(-3.13)\end{array}$ & $\begin{array}{r}-16.226 \\
(-0.48)\end{array}$ & $\begin{array}{r}16.477 \\
(0.49)\end{array}$ & $\begin{array}{r}19.617 \\
(0.35)\end{array}$ \\
\hline PPE & $\begin{array}{l}-0.000 \\
(-0.01)\end{array}$ & $\begin{array}{r}0.032 \\
(0.96)\end{array}$ & $\begin{array}{l}-0.099^{* *} \\
(-2.39)\end{array}$ & $\begin{array}{l}-0.095^{* *} \\
(-2.30)\end{array}$ & $\begin{array}{c}-11.609 \\
(-0.57)\end{array}$ & $\begin{array}{r}-12.427 \\
(-0.44)\end{array}$ & $\begin{array}{r}-10.896 \\
(-0.28)\end{array}$ \\
\hline SGA & $\begin{array}{r}0.011 \\
(0.39)\end{array}$ & $\begin{array}{l}-0.010 \\
(-0.20)\end{array}$ & $\begin{array}{l}-0.060 \\
(-1.26)\end{array}$ & $\begin{array}{l}-0.074 \\
(-1.43)\end{array}$ & $\begin{array}{l}40.890^{* * *} \\
(2.67)\end{array}$ & $\begin{array}{l}-8.267 \\
(-0.45)\end{array}$ & $\begin{array}{l}8.765 \\
(0.17)\end{array}$ \\
\hline Constant & $\begin{array}{l}-0.203 \\
(-1.40)\end{array}$ & $\begin{array}{l}-0.271^{*} \\
(-1.92)\end{array}$ & $\begin{array}{r}0.285 \\
(1.40)\end{array}$ & $\begin{array}{c}0.317^{*} \\
(1.80)\end{array}$ & $\begin{array}{l}-0.548 \\
(-0.00)\end{array}$ & $\begin{array}{c}185.939^{* *} \\
(2.30)\end{array}$ & $\begin{array}{r}195.086 \\
(1.48)\end{array}$ \\
\hline YR & Yes & Yes & Yes & Yes & Yes & Yes & Yes \\
\hline $\bar{N}$ & 337 & 337 & 337 & 337 & 337 & 337 & 336 \\
\hline$R^{2}$ & 0.573 & 0.564 & 0.401 & 0.390 & 0.092 & 0.067 & 0.047 \\
\hline Adj. $R^{2}$ & 0.553 & 0.543 & 0.373 & 0.361 & 0.0496 & 0.0236 & 0.00281 \\
\hline $\mathrm{F}$-stat. & 15.36 & 13.59 & 5.901 & 9.808 & 2.164 & 2.239 & 1.007 \\
\hline
\end{tabular}

두 집단의 장기재무성과 차이는 SPAC 변수의 유의성으로 판단된다. 영업성과 dEBITDA $(-1,+1)$ 와 $\operatorname{dEBITDA}(-1,+2)$ 대한 회귀분석결과에서 SPAC 변수는 유의하지 않다. 종속 
한국증권학회지 제 51 권 1호 (2022)

변수를 영업현금흐름으로 변경한 분석 또한 SPAC 변수의 결과는 변하지 않는다. <표 $7>$ 의 차이분석과 동일한 결과이다. 그 외에 $\mathrm{LEV}, \mathrm{ROA}$ 변수의 계수가 유의한 음(-)의 수치이다.

장기주식성과의 경우 12 개월, 24 개월, 36 개월 주가성과 모두 두 집단의 차이가 확인되지 않는다. 영업성과와 비교하면 통제변수의 유의성도 약화된다. 상장기업의 영업성과에 비해 주식성과 예측이 어렵다고 해석할 수 있겠다.

장기재무성과에 대한 회귀분석결과는 차이분석과 정확하게 일치하며, 스팩합병 상장기업의 재무성과는 우려와 다르게 일반상장기업보다 열등하지 않다. 또한, 소규모기업과 비제조업 기업에 상장경로를 제공하는 점에서 스팩합병 상장의 유용성은 분명하다.

\section{4 스팩특성과 재무성과}

스팩특성의 상장이후 재무성과에 대한 영향을 분석해 본다. Lee(2017)가 합병이전 스팩의 단기주식성과를 분석했다면 본 연구는 합병이후 장기성과를 분석하는 의의가 있다. 스팩 상장정보와 합병정보 등의 스팩특성 변수를 추가하여 스팩합병 상장기업에 대한 재무성과를 검증한다. 스팩 상장정보는 청약경쟁률(CPR_IPO), 기관투자자배정비율(ALLC_INST)이며,

\section{〈표 9〉스팩특성과 재무성과}

재무성과 측정치 $\operatorname{dEBITDA}(-1,+1), \mathrm{dCFO}(-1,+1), \operatorname{BHAR}(+1 \mathrm{M},+12 \mathrm{M}), \mathrm{BHAR}(+1 \mathrm{M},+24 \mathrm{M})$ 이 종속 변수이다. 재무성과변수의 설명은 <표 $7>$ 에 기술되어 있다. 제조업더미변수(MNF)는 제조업이면 1 의 값을 나머지는 0 의 값을 가진다. 스팩 대비 피합병법인 총자산비율(TA_R)은 피합병법인 총자산을 스팩의 총자산으로 나눈 값이다. 나머지 재무비율 및 기업특성변수의 정의는 <표 $4>$ 과 <표 $5>$ 에 제시되어 있다. ( )은 이분산성을 고려한 t값이며, ${ }^{* * *},{ }^{* *},{ }^{*}$ 는 각각 $1 \%, 5 \%, 10 \%$ 수준에서 통계적으로 유의함을 나타낸다.

\begin{tabular}{lrrrr}
\hline & $(1)$ & \multicolumn{1}{c}{$(2)$} & $(3)$ & $(4)$ \\
& $\mathrm{dEBITDA}(-1,+1)$ & $\mathrm{dCFO}(-1,+1)$ & $\mathrm{BHAR}(+1 \mathrm{M},+12 \mathrm{M})$ & $\mathrm{BHAR}(+1 \mathrm{M},+24 \mathrm{M})$ \\
\hline SIZE & $0.057(1.58)$ & $0.036(0.52)$ & $-9.811(-0.67)$ & $-5.215(-0.25)$ \\
LEV & $-0.131(-0.81)$ & $0.011(0.05)$ & $20.156(0.24)$ & $-26.950(-0.26)$ \\
CR & $-0.010(-1.10)$ & $0.003(0.23)$ & $-11.796(-3.37)^{* * *}$ & $-10.064(-2.43)^{* *}$ \\
ROA & $-1.244(-4.20)^{* * *}$ & $-1.246(-3.24)^{* * *}$ & $39.222(0.48)$ & $24.073(0.39)$ \\
TATOV & $0.039(0.93)$ & $0.068(1.03)$ & $-18.688(-1.12)$ & $-22.393(-0.98)$ \\
CASH & $0.179(0.73)$ & $-0.151(-0.45)$ & $122.827(1.37)$ & $178.498(2.20)^{* *}$ \\
PPE & $0.084(0.63)$ & $-0.194(-0.95)$ & $54.856(0.86)$ & $7.430(0.11)$ \\
SGA & $-0.074(-0.59)$ & $-0.132(-0.89)$ & $14.862(0.32)$ & $-51.251(-1.12)$ \\
MR & $0.000(0.68)$ & $0.000(0.33)$ & $-0.062(-1.10)$ & $-0.108(-1.66)$ \\
CPR_IPO & $0.000(1.03)$ & $0.000(0.37)$ & $0.069(0.77)$ & $0.200(1.75)^{*}$ \\
ALLC_INST & $0.295(1.39)$ & $0.422(1.18)$ & $129.890(1.86)^{*}$ & $111.118(1.18)$ \\
TA_R & $-0.000(-0.89)$ & $-0.000(-0.17)$ & $-0.002(-0.35)$ & $0.002(0.19)$ \\
Constant & $-1.146(-1.64)$ & $-0.829(-0.64)$ & $90.377(0.36)$ & $43.328(0.12)$ \\
\hline N & 57 & 57 & & 57 \\
R $^{2}$ & 0.671 & 0.476 & 0.234 & 0.241 \\
Adj. R ${ }^{2}$ & 0.581 & 0.333 & 0.0251 & 0.0344 \\
F-stat. & 5.199 & 4.278 & 1.882 & 1.333 \\
\hline
\end{tabular}


합병 관련 정보로는 합병비율(MR)과 스팩 대비 피합병법인 총자산비율(TA_R)이 사용 된다.20)

$<$ 표 9>의 영업성과 $\mathrm{dEBITDA}(-1,+1)$ 과 $\mathrm{dCFO}(-1,+1)$ 에 대한 회귀분석결과는 스팩특성 변수의 유의성을 보여주지 못한다. 영업성과를 주가성과로 변경한 모형 (3)과 모형 (4)의 회귀분석결과는 각각 기관투자자배정비율(ALLC_INST)과 청약경쟁률(CPR_IPO)이 $10 \%$ 수준에서 유의하다. 스팩공모에 참여하는 기관투자자 지분과 청약경쟁률의 합병이후 주가성과에 대한 긍정적 효과가 발견된다. 공모참여 기관투자자의 긍정적 역할과 스팩상장 이후 모니터링 효과를 유추할 수 있다.

Lee(2017)는 스팩상장일부터 합병발표일과 합병발표일부터 합병기일의 초과수익률을 분석하여, 스팩보다 피합병기업의 자산총계와 자본총계가 클수록 높은 초과수익률을 확인한다. 반면 본 연구는 피합병기업과 합병기업의 총자산비율의 유의성은 발견되지 않는다. 다만 스팩특성의 합병이후 주가성과에 대한 유의미한 효과를 확인하였으며, 스팩특성과 스팩성과에 대한 체계적인 향후 연구의 필요성을 제기한다.

\section{5. 결론}

국내 스팩합병 상장의 급속한 성장과 함께 스팩합병 상장기업의 연구가 확대 및 증가하고 있다. 스팩합병 상장기업과 일반상장기업의 특성비교 및 상장이후 주가성과 비교분석까지 진전된다. 하지만, 장기주가성과를 분석한 연구가 부족할 뿐만 아니라 스팩합병 상장기업과 일반상장기업의 주가성과 비교가 미흡하다. 또한, 스팩합병 상장기업의 영업성과를 분석한 국내연구는 확인되지 않는다.

기존 우회상장 규제강화 이후 스팩합병 상장이 대안으로 급부상한다. 그렇다면 스팩합병 상장은 기존 우회상장이 야기한 부작용에서 자유로울 수 있는가? 스팩합병 상장은 기존 우회상장에 비해 상장이후 부실화를 방지하는 안전장치가 존재한다. 스팩상장과정에서 조달된 공모자금은 금융기관에 예치되고 합병성공이후 합병기업의 자산으로 편입된다. 자금조달효과가 부재한 우회상장에 비해 우수한 특징이다. 비상장기업이 합병 추진주체가 되는 우회상장은 신속한 상장을 달성하고자 부실 상장기업과 합병한 탓에 조기부실화의 부작용이 컸다. 합병을 추진하는 스팩경영진의 보상이 합병이후 성과와 연계되어 있어, 스팩합병 상장은 우량한 비상장 기업과의 합병하고 상장시킬 유인이 높다. 피합병법인에 요구되는 상장요건 또한 일반상장과 거의 동일하다.

스팩의 긍정적 특성과 성장세를 고려한다면, 과연 스팩합병 상장이 기존의 일반상장과 차별화된 유용성과 가치를 제공하는지 조사할 필요가 있다. 물론 기존 선행연구들은 이미 일반상장과 스팩합병 상장기업의 상이한 특성을 발견했지만, 상장이후의 장기재무성과 분석은 미흡하다. 합병상장 기업의 재무성과가 일반상장보다 열악하지 않다면 스팩합병 상장의 가치는 높을 것이다.

20) Lee(2017)를 참고하여 합병비율과 피합병법인 대비 스팩의 총자산비율과 스팩정보 일부를 추가하여 회귀분석한다. 
한국증권학회지 제 51 권 1 호 (2022)

만약 스팩합병 상장의 재무성과가 해외선행연구와 동일하게 일반상장기업보다 열등하다면 이를 보완할 정책이 수립되어야 한다.

본 연구는 스팩합병 상장기업의 유용성을 평가하기 위해서 스팩합병 상장기업의 특성과 재무성과를 분석하여 다음의 결과를 발견한다. 첫 번째, 스팩합병 상장기업은 기존의 일반상장 기업과 차별화된다. 일반상장기업보다 기업규모가 작고, 비제조업의 비중이 높다. 정보비대칭성이 높고 당장 코스닥시장에 진입하기 어려운 기업에 상장기회를 제공한다. 두 번째, 일반상장기업과 상장이후 재무성과를 비교한 결과가 열등하지 않다. 스팩합병 상장기업의 열등한 성과를 제시한 선행연구와는 상이한 결과이다. 마지막으로, 스팩공모 당시의 기관투자자배정비율과 청약경쟁률이 스팩합병 상장이후 주가성과에 긍정적이다. 스팩을 주도하는 기관투자자의 긍정적 효과가 확인된 점에서 의의가 있다.

본 연구의 실증결과를 바탕으로 스팩합병 상장은 당장 코스닥시장에 진입이 어려운 우량 중소기업에 신속한 상장경로를 제공하고 있어 가치가 충분하다. 또한, 스팩공모에 참여하는 기관투자자의 긍정적 효과도 유추할 수 있다. 스팩특성과 합병성공에 대한 연구가 필요하며 이는 추후 연구로 남겨둔다. 
Long-term Performance of Going Public through SPACs

\section{References}

Aharony, J., C. Lin, and M. P. Loeb, 1993, Initial Public Offerings, Accounting Choices, and Earnings Management, Contemporary Accounting Research, Vol. 10, pp. 61-81.

Barber, B., and J. Lyon, 1997, Detecting Long-run Abnormal Stock Returns: The Empirical Power and Specification of Test Statistics, Journal of Financial Economics, Vol. 43, pp. 341-372.

Campbell, J. and E. Wasley, 1985, Measuring Security Price Performance Using Daily NASDAQ Returns, Journal of Financial Economics, Vol. 14, pp. 3-31.

Cha, J. Y., Y. T. Seo, and B. S. Yoon, 2019, A Study on the KOSDAQ Listing Methodology of Unlisted Companies: Comparison between IPO and SPAC, Asia Pacific Journal of Small Business, Vol. 41 (2), pp. 51-78.

Choi, K., and M. Kim, 1997, Initial Public Offerings and Earnings Management, Korean Accounting Review, Vol. 22 (2), pp. 1-27.

Choi, J. H., 2006, Audit Quality and Earnings Management of Initial Public Offerings Firms, Korean Accounting Review, Vol. 31 (4), pp. 113-143.

Choi, J. S., Y. M. Kwak, and J. H. Baek, 2010, Earnings Management around Initial Public Offerings in KOSDAQ Market Associated with Managerial Opportunism, Korean Accounting Review, Vol. 35 (3), pp. 37-80.

Cumming, D., L. H. Haß, and D. Schweizer, 2014, The Fast Track IPO - Success Factors for Taking Firms Public with SPACs, Journal of Banking and Finance, Vol. 47, pp. 198-213.

Datar, V., E. Emm, and U. Ince, 2012, Going Public through the Backdoor: A Comparative Analysis of SPACs and IPOs, Banking and Finance Review, Vol. 4, pp. 17-36.

Dimitrova, L., 2017, Perverse Incentives of Special Purpose Acquisition Companies, the "Poor Man's Private Equity Funds, Journal of Accounting and Economics, Vol. 63, pp. 99-120.

Erickson, M., and S. Wang, 1999, Earning Management by Acquiring Firms in Stock for Stock Mergers, Journal of Accounting and Economics, Vol. 27, pp. 149-176.

Floros, I. V., and T. R. A. Sapp, 2011, Shell Games: On the Value of Shell Companies, Journal of Corporate Finance, Vol. 17, pp. 850-867.

Friedlan, J. M., 1994, Accounting Choices of Issuers of Initial Public Offerings, Contemporary Accounting Research, Vol. 11 (1), pp. 1-31.

Hong, J., and D. Yang, 2021, An Empirical Study on the Determinants of Unlisted Korean Firms Going Public through SPAC Listing, Korean Journal of Business Administration, Vol. 34 (3), pp. 527-557. 
한국증권학회지 제51권 1호 (2022)

Ignatyeva, E., C. Rauch, and M. Wahrenburg, 2013, Analyzing European SPACs, Journal of Private Equity, Vol. 17, pp. 64-79.

Ihm, B., 1997, Short-run and long-run Performance of IPOs, The Korean Journal of Financial Management, Vol. 14 (2), pp. 253-271.

Jenkinson, T., and M. Sousa, 2011, Why SPAC Investors Should Listen to the Market, Journal of Applied Finance, Vol. 2, pp. 1-21.

Jeong, J. W., and G. S. Bae, 2006, Earnings Management by Acquiring and Target Firms in Related Firm Mergers, Korean Accounting Review, Vol. 31 (2), pp. 57-90.

Jeong, J. W., 2007, Conflicts of Interest between Controlling Shareholder and External Shareholders and Long-term Performance of Acquiring Firms after Mergers, Korean Accounting Review, Vol. 32 (3), pp. 123-155.

Jung, H. C., and K. H. Park, 1999, The Long-run Performance of Mergers and Acquisitions, The Korean Journal of Financial Management, Vol. 16 (1), pp. 83-114.

Kang, H., and S. Kim, 2009, Long-Run Performance of Mergers and Acquisitions in Korea, Journal of Money \& Finance, Vol. 23 (4), pp. 63-101.

Kang, H. S., and J. W. Suh, 2010, The Effects of Mergers and Acquisitions on Acquiring Firms' Performance in KOSDAQ Market, Korean Journal of Financial Studies, Vol. 39 (2), pp. 191-223.

Kang, S. H., and J. S. Kim, Comparative Analysis of Different Types of IPOs in the KOSDAQ Market, Issue Report, Korea Capital Market Institute, 2018, http://www.kcmi.re.kr/report/ report_view?report_no=880.

Kim, K. J., M. Kim, and J. Y. Jeon, 2004, Why Do Firms Manage Earnings after Initial Public Offerings?, Korean Accounting Review, Vol. 29 (4), pp. 87-116.

Kim, A. K., 2008, A Study on Introduction of Special Purpose Acquisition Companies (SPAC) into Korean Legal System, The Korean Journal of Securities Law, Vol. 9 (2), pp. 271-314.

Kim, B. J., 2010a, The Introduction of the Special Purpose Acquisition Company(SPAC) and Its Legislative Implications in Korea, Business Law Review, Vol. 24 (2), pp. 119-148.

Kim, H. J., 2010b, The Financial and Legal Characteristics of "Special Purpose Acquisition Company (SPAC)" in the Korean Capital Markets, Business Law Review, Vol. 24 (3), pp. 329-352.

Kim, J. S., Y. Park, and S. Lee, 2014, Analysis on Dysfunction of the Backdoor Listing in Korea, Asian Review of Financial Research, Vol. 27 (3), pp. 493-528.

Kim, J. E., and H. J. Kang, 2019, A Study on Post-Listing Performance of Merged Firms: Focus on Korean Special Purpose Acquisition Companies (SPAC), Journal of International Trade \& Commerce, Vol. 15 (5), pp. 493-507. 
Long-term Performance of Going Public through SPACs

Kim, D. H., and M. Y. Lee, 2019, A Study on the Long-term Performance of Companies According to IPO Type, The Journal of Business Education, Vol. 33 (2), pp. 87-115.

Kolb, J., and T. Tykvova, 2016, Going Public via Special Purpose Acquisition Companies: Frogs Do Not Turn into Princes, Journal of Corporate Finance, Vol. 40, pp. 80-96. Lakicevic, M., and M. Vulanovic, 2011, Determinants of Mergers: A Case of Specified Purpose Acquisition Companies (SPACs), Investment Management and Financial Innovations, Vol. 8 (3), pp. 114-120.

Lakicevic, M., and M. Vulanovic, 2013, A Story on SPACs, Managerial Finance, Vol. 39, pp. 384-403.

Lakicevic, M., Y. Shachmurove, and M. Vulanovic, 2014, Institutional Changes of Specified Purpose Acquisition Companies (SPACs), North American Journal of Ecomomics and Finance, Vol. 28, pp. 149-169.

Lee, H. S., 2014, Introduction of SPAC and It's Effects, Management \& Information Systems Review, Vol. 33 (2), pp. 263-279.

Lee, J. Y., J. G. Park, and C. G. Kim, 2005, A Study on the Earnings Management of KOSDAQ IPO Firms, Korean Journal of Business Administration, Vol. 18 (6), pp. 2681-2700

Lee, W. B., 2017, The Listing Performance of Merger of SPAC and Small and Medium Sized Enterprises, Korean Journal of Financial Studies, Vol. 46 (3), pp. 591-622.

Loughran, T., and J. Ritter, 1997, The Operating Performance of Firms Conducting Seasoned Equity Offerings, Journal of Finance, Vol. 52, pp. 1823-1850.

Louis, H., 2004, Earning Management and Market Performance of Acquiring Firms, Journal of Financial Economics, Vol. 74, pp. 121-148.

Min, J. K., and S. M. Cha, 2017, A Study on Earnings Management of IPO Firms Merged with SPAC, Korean Accounting Journal, Vol. 26 (4), pp. 161-189.

Oh, Y. P., 2010, A Leal Study on Korean Special Purpose Acquisition Company, Korean Journal of Banking and Financial Law, Vol. 3 (1), pp. 127-164.

Oh, S., and H. H. Han, 2014, The Short- and Long-term Performance of Venture-backed IPO Kosdaq Firms and the Roles of Venture Capitals in Korea, Asian Review of Financial Research, Vol. 27 (3), pp. 457-491.

Ritter, J. R., 1991, The Long-run Performance of Initial Public Offerings, Journal of Finance, Vol. 46 (1), pp. 3-27.

Teoh, S. H., I. Welch, and T. J. Wong, 1998, Earnings Management and the Long-run Market Performance of Initial Public Offerings, Journal of Finance, Vol. 53 (6), pp. 1935-1974. 